\title{
HETEROGENEIDADE INDUSTRIAL REGIONAL: UM COMPARATIVO ENTRE AS UFS DA REGIÃO CENTRO-OESTE E SÃO PAULO
}

Murilo José de Souza Pires

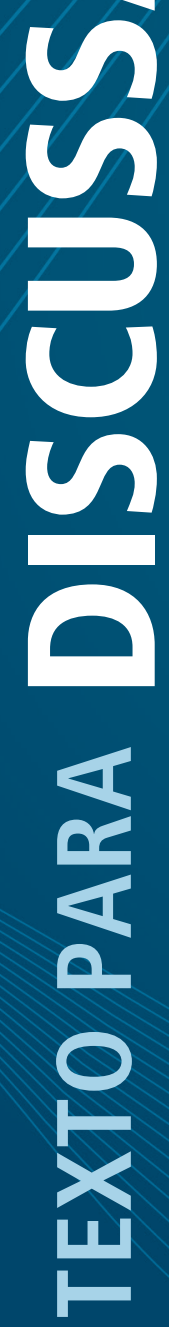





\section{TEXTO PARA DISCUSSÃO}

Brasília, agosto de 2021

\section{HETEROGENEIDADE INDUSTRIAL REGIONAL: UM COMPARATIVO ENTRE} AS UFS DA REGIÃO CENTRO-OESTE E SÃO PAULO ${ }^{1}$

Murilo José de Souza Pires²

1. As opiniões expressas neste texto são de inteira responsabilidade do autor. Este documento não representa, necessariamente, a posição do Ipea. 0 autor registra seus agradecimentos pelos comentários e sugestões de melhoramentos ao texto realizados por Aristides Monteiro Neto, do Ipea, e Fernando Cezar de Macedo Mota, do Instituto de Economia da Universidade Estadual de Campinas (IE/Unicamp). Quaisquer erros no trabalho ou omissões são de responsabilidade exclusiva do autor 2. Técnico de Planejamento e Pesquisa da Diretoria de Estudos e Políticas Regionais, Urbanas e Ambientais (Dirur) do Ipea. 


\section{Governo Federal}

Ministério da Economia

Ministro Paulo Guedes

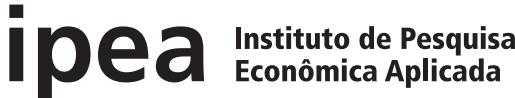

Fundação pública vinculada ao Ministério da Economia, o Ipea fornece suporte técnico e institucional às ações governamentais - possibilitando a formulação de inúmeras políticas públicas e programas de desenvolvimento brasileiros - e disponibiliza, para a sociedade, pesquisas e estudos realizados por seus técnicos.

Presidente

Carlos von Doellinger

Diretor de Desenvolvimento Institucional

Manoel Rodrigues Junior

Diretora de Estudos e Políticas do Estado, das Instituições e da Democracia

Flávia de Holanda Schmidt

Diretor de Estudos e Políticas Macroeconômicas José Ronaldo de Castro Souza Júnior

Diretor de Estudos e Políticas Regionais, Urbanas e Ambientais

Nilo Luiz Saccaro Júnior

Diretor de Estudos e Políticas Setoriais de Inovação e Infraestrutura

André Tortato Rauen

Diretora de Estudos e Políticas Sociais Lenita Maria Turchi

Diretor de Estudos e Relações Econômicas e Políticas Internacionais

Ivan Tiago Machado Oliveira

Assessor-chefe de Imprensa e Comunicação André Reis Diniz

Ouvidoria: http://www.ipea.gov.br/ouvidoria URL: http://www.ipea.gov.br

\section{Texto para Discussão}

Publicação seriada que divulga resultados de estudos e pesquisas em desenvolvimento pelo Ipea com o objetivo de fomentar o debate e oferecer subsídios à formulação e avaliação de políticas públicas.

(C) Instituto de Pesquisa Econômica Aplicada - ipea 2021

Texto para discussão / Instituto de Pesquisa Econômica Aplicada.- Brasília : Rio de Janeiro : Ipea , 1990-

ISSN 1415-4765

1.Brasil. 2.Aspectos Econômicos. 3.Aspectos Sociais. I. Instituto de Pesquisa Econômica Aplicada.

CDD 330.908

As publicações do Ipea estão disponíveis para download gratuito nos formatos PDF (todas) e EPUB (livros e periódicos).

Acesse: http://www.ipea.gov.br/portal/publicacoes

As opiniões emitidas nesta publicação são de exclusiva e inteira responsabilidade dos autores, não exprimindo, necessariamente, o ponto de vista do Instituto de Pesquisa Econômica Aplicada ou do Ministério da Economia.

É permitida a reprodução deste texto e dos dados nele contidos, desde que citada a fonte. Reproduções para fins comerciais são proibidas.

JEL: R11.

DOI: http://dx.doi.org/10.38116/td2681 


\section{SUMÁRIO}

SINOPSE

ABSTRACT

1 INTRODUÇÃO

7

2 UMA SISTEMATIZAÇÃO DAS EVIDÊNCIAS TEÓRICAS SOBRE

A HETEROGENEIDADE INDUSTRIAL EM ECONOMIAS PERIFÉRICAS.

3 FATOS ESTILIZADOS SOBRE A PT INDUSTRIAL ENTRE AS

REGIÕES BRASILEIRAS

4 A EVOLUÇÃO DAS EXPORTAÇÕES DE PRODUTOS MANUFATURADOS

DA REGIÃO CENTRO-OESTE

5 UMA COMPARAÇÃO ENTRE A PT INDUSTRIAL SETORIAL POR

FATORES DE COMPETITIVIDADE DAS UFS QUE CONSTITUEM A

REGIĨO CENTRO-OESTE VIS-À-VIS AO ESTADO DE SÃO PAULO

6 OBSERVAÇÕES FINAIS. 



\section{SINOPSE}

As economias das Unidades da Federação (UFs) da regiáo Centro-Oeste, desde os anos 1990, estão passando por uma modificação em seu estilo de desenvolvimento, visto que os fatores externos se tornaram mais pulsantes vis-à-vis aos fatores internos como determinantes nas transformaçôes das estruturas produtivas deste espaço regional. Mais conectadas aos mercados internacionais, estas economias locais aceleraram o processo de modernização de suas estruturas produtivas, porém, sem romper com sua condição de subdesenvolvimento. É neste contexto que tece toda a trama desta investigação, quer dizer, verificar se há alguma redução no hiato existente entre a produtividade média do trabalho dos setores industriais por fatores de competitividade nas UFs que formam a região Centro-Oeste vis-à-vis ao estado de São Paulo, no período de 1996 a 2016. Para tanto, adota-se o método histórico-estrutural como meio para testar e validar a evidência empírica que o diferencial de produtividade média do trabalho dos setores industriais por fatores de competitividade centro-oestinos vis-à-vis ao estado de São Paulo vem se reduzindo no interstício de 1996 a 2016. Neste sentido, os setores industriais por fatores de competividade da regiáo Centro-Oeste que apresentaram maior convergência em termos de produtividade do trabalho (PT) industrial vis-à-vis ao estado de Sáo Paulo foram os baseados em recursos naturais, diferenciado, intensivo em escala e intensivo em trabalho. Com exceção do Distrito Federal, nenhuma UF do Centro-Oeste apresentou uma redução na lacuna entre o diferencial de PT industrial vis-à-vis ao estado de São Paulo naquilo que se refere ao setor baseado em ciências. Deste modo, é importante sublinhar que o grau de heterogeneidade entre os setores industriais que constituem as UFs do Centro-Oeste e o estado de Sáo Paulo apresentou, no interstício de 1996 a 2016, um declínio, visto que os seus valores se aproximaram mais da média de cada UF, sinalizando, por conseguinte, que a difusão do progresso técnico seguiu pelo caminho de uma maior homogeneização inter-regional. Porém, é importante acentuar que isto não significou que UFs analisadas tenham superado a dualidade existente entre as empresas que modernizaram e aquelas que ainda se mantiveram agarradas aos grilhôes das técnicas arcaicas e tradicionais. Isto reforça a dependência tecnologia deste espaço regional em relaçáo ao padrão tecnológico estabelecido nos países centrais, uma vez que as UFs da regiấo Centro-Oeste possuem pouca capacidade de geraçáo endógena de ciência, tecnologia e inovação (CT\&I). Este fato reforça a necessidade de formulação de estratégias estaduais em CT\&I para reduzirem a dependência destes estados vis-à-vis às inovaçôes tecnológicas que são produzidas nos países centrais.

Palavras-chave: progresso técnico; heterogeneidade estrutural; Centro-Oeste. 


\section{ABSTRACT}

The economies of the Midwest region, since the 1990s, have been undergoing a change in their development style, as external factors have become more pulsating vis-à-vis internal factors as determinants in the transformation of productive structures of this regional space. More connected to international markets, these local economies accelerated the process of modernizing their productive structures, but without breaking with their condition of underdevelopment. It is in this context that the whole plot of this investigation is woven, that is, to verify whether there is any reduction in the gap between the average labor productivity of the industrial sectors due to competitiveness factors in the states that form the Midwest region vis-à-vis the state of São Paulo in the period from 1996 to 2016. For this purpose, the historical-structural method is adopted as a means to test and validate the empirical evidence that the average productivity differential of the industrial sectors due to centralostatic competitiveness factors vis-à-vis -vis to the state of São Paulo has been decreasing in the interstitium from 1996 to 2016. In this sense, the industrial sectors due to competitiveness factors in the Midwest region that showed greater convergence in terms of industrial labor productivity vis-à-vis the state from São Paulo were those based on natural resources, differentiated, intensive in scale and intensive in work. With the exception of the Federal District, no state in the Midwest showed a reduction in the gap between the productivity differential of industrial work vis-à-vis the state of São Paulo in what concerns the science-based sector. Thus, it is important to underline that the degree of heterogeneity between the industrial sectors that constitute the states of the Midwest and São Paulo presented, in the interstitium from 1996 to 2016, a decline, since their values were closer to the average of each signaling, therefore, that the diffusion of technical progress has followed the path of greater interregional homogenization. However, it is important to emphasize that this did not mean that these states have overcome the duality between the companies that modernized and those that still remained clinging to the fetters of archaic and traditional techniques. This reinforces the technological dependence of this regional space in relation to the technological standard established in the central countries, since the states of the Midwest region have little capacity for endogenous generation of science, technology and innovation (CT\&I). This fact reinforces the need to formulate state strategies in science, technology and innovation (ST\&I) to reduce the dependence of these states vis-à-vis the technological innovations that are produced in central countries

Keywords: technical progress; structural heterogeneity; Midwest. 


\section{INTRODUÇÃO}

Uma temática que ganhou expressão no debate sobre a questão regional brasileira refere-se à importância que o espraiamento espacial do vetor industrial teve no processo de desenvolvimento nacional, sobretudo, no período do Modelo de Substituição de Importaçóes, no interstício de 1930 a 1980, quando o estado de São Paulo se tornou o centro dinâmico e de integraçáo dos mercados nacionais, como defendido por Cano (2007a).

Com o processo de reestruturação e desregulamentação econômica, iniciado nos anos de 1990, a tese de integração do mercado nacional desde São Paulo derivou duas outras interpretaçóes que se consubstanciaram nas teses da desconcentraçấo concentrada e da fragmentação da nação, as quais retratam hermenêuticas díspares sobre o fenômeno da desconcentração regional vivenciado nas regiôes brasileiras no período posterior aos anos 1990 .

Ainda que a questáo da desconcentração regional seja um fenômeno complexo por se apresentar a consciência do pesquisador em suas múltiplas facetas, observa-se que as inversóes industriais, ao se concentrarem em regióes especificas do território, acabaram reforçando a tese dos desequilíbrios regionais, posto que os investimentos indústrias acabam carregando os vetores da modernização da economia, o que proporciona modificaçôes no modo de alocar os fatores de produção nas unidades produtivas. Com isso, ao serem distribuídos de forma disforme no espaço regional, podem causar uma rigidez na brecha que há entre o lado moderno e atrasado da economia.

Isto aconteceu, porque a expansão do progresso técnico, enquanto objetivo da acumulação de capital, se concretizou no espargimento desigual do conhecimento cientifico (que se substancia como elemento indutor das inovaçóes tecnológicas derivadas da criação de novos produtos, na conquista de novas fontes de matérias-primas e na abertura de novos mercados) no vetor espacial determinando trajetórias distintas do processo de modernizaçáo nas estruturas produtivas regionais. Assim, uma reflexão sobre o papel da expansão da produtividade do trabalho (PT) industrial - usado como proxy do progresso técnico, no contexto da questáo regional - torna-se instigante, sobretudo quando se consubstancia em uma economia periférica, como é a brasileira, marcada pelo subdesenvolvimento. 
Como a PT industrial se irradia de forma assimétrica pelo tecido industrial das economias periféricas, visto que se estruturaram de forma tardia e dependente dos países centrais, o seu avanço pelos espaços regionais acaba reforçando o grau de heterogeneidade existente na estrutura produtiva, uma vez que os seus impulsos se propagam de forma desigual entre as unidades industriais.

O reflexo disto foi a constituição de estruturas produtivas duais que estavam, no mesmo espaço e tempo, projetando uma modernidade que não teve potencial de transformar os resquícios produzidos pelas economias atrasadas e de subsistência, amarrando, assim, o país nos grilhôes do subdesenvolvimento. Este fenômeno tornou-se um dilema nacional, pois o progresso técnico náo conseguiu inocular nas estruturas produtivas arcaicas as forças de transformação que superassem o hiato existente entre o moderno e o atrasado.

É no entrelaçamento das contradiçóes expostas pelo subdesenvolvimento nacional que o avanço da industrializaçáo das regiôes nacionais vai se colocando, em especial no estado de Sáo Paulo que, desde os anos 1930, tornou-se o centro dinâmico do capitalismo nacional. Sua pujança avança até os anos 1970, quando os programas de desconcentração dos investimentos ganham expressão por meio do II Plano Nacional de Desenvolvimento - PND (1975-1979). No entanto, a crise fiscal e financeira dos anos 1980 aprofundaram os desajustes macroeconômicos, o que lançou a economia nacional em um espiral hiperinflacionário.

Reformas apregoadas pelo Consenso de Washington são postas na renegociação da dívida externa brasileira, de 1992 a 1994, e o processo de abertura econômica e desregulamentação tornaram-se o caminho para a construçáo de um novo estilo de desenvolvimento. É neste contexto de integração aos mercados internacionais que os projetos de desenvolvimento são estabelecidos, sobretudo, guiados pelos Eixos Nacionais de Integração e Desenvolvimento (Enid), que tinham por finalidade concentrar um conjunto de investimentos produtivos e de infraestrutura para melhorarem a competitividade das regiôes brasileiras no cenário internacional.

É em meio às transformaçôes vivenciadas pela economia brasileira que a região Centro-Oeste vai impulsionar ainda mais a modernização de suas estruturas produtivas, a qual já vinha ganhando força e expressão desde meados dos anos 1960, quando os planos de desenvolvimento regional do governo federal criaram as condiçóes objetivas para a adaptação do cerrado ao circuito de valorizaçáo do capital internacional. 
Com forte expansão da produção de commodities agrícolas, os investimentos industrias vieram se cristalizando em meio aos incentivos e benefícios fiscais proporcionados pelas Unidades da Federação (UFs) centro-oestinas, como também crédito e inovaçôes tecnológicas proporcionados pelo estado nacional e pela iniciativa privada. É neste contexto que o setor industrial do Centro-Oeste acelera sua modernizaçáo, porém, sem equalizar a atávica heterogeneidade da estrutura produtiva e a concentração fundiária em médias e grandes propriedades rurais. ${ }^{1}$

Assim, o objetivo deste trabalho é aprofundar um questionamento que não ficou concluso em Pires (2016), quando discutiu a questáo da heterogeneidade industrial no Centro-Oeste. Em linhas gerais, o trabalho apontou que, entre os anos de 2000 e 2010, houve uma redução no hiato existente entre a produtividade média do trabalho industrial das UFs do Centro-Oeste vis-à-vis ao estado de São Paulo, porém, retratando dois momentos específicos do tempo.

$\mathrm{Na}$ ocasião, a análise estava delimitada para as estruturas industriais em suas múltiplas escalas regionais, quer dizer, em nível regional, de UFs, de microrregióes e municípios; entretanto, sem a preocupação em desvelar como o fenômeno se objetivou na estrutura setorial que entrelaça com os seus fios, o tecido industrial regional. Neste sentido, o objetivo deste trabalho é verificar se há alguma redução no hiato existente entre a produtividade média do trabalho dos setores industriais por fatores de competitividade das UFs que formam a região Centro-Oeste vis-à-vis ao estado de São Paulo no período de 1996 a 2016.

Mesmo que as evidências teóricas apontem que as estruturas industriais das economias periféricas e subdesenvolvidas como a brasileira sejam marcadas atavicamente pela heterogeneidade estrutural, como foram destacados nos trabalhos de Pinto (2000), Kupfer e Rocha (2004), Cimoli et al. (2005), Bárcena et al. (2010), Porcile, Yamila e Catela (2012), Squeff e Nogueira (2013), Cavalcante e De Negri (2014), Pires (2016), e Bielschowsky e Torres (2018), ainda assim adota-se a hipótese, alicerçada em Pires (2016), que o diferencial de produtividade média do trabalho dos setores industriais por fatores de competitividade centro-oestinos vis-à-vis ao estado de São Paulo vem se reduzindo no interstício de 1996 a 2016.

1. Para maiores detalhes, ver Pires (2008). 
No entanto, faz-se necessário delimitar o escopo da análise, uma vez que a complexidade da temática descerra vários questionamentos que podem desviar a investigação do seu leito natural que se consubstancia no objetivo do estudo. Isto acontece porque o fenômeno da heterogeneidade do setor industrial regional pode ser investigado em suas múltiplas faces, retratando, por conseguinte, as diversas singularidades que constituem o fenômeno em sua complexidade integral.

Assim, a essência do questionamento proposto não se objetiva na compreensão do principium que determina os diferenciais de produtividade industrial em seus desdobramentos regionais. O olhar proposto na investigação é verificar como o subdesenvolvimento está interferindo no grau de heterogeneidade dos setores industriais em suas múltiplas escalas regionais tendo como ponto focal a economia paulista; porém, dando ênfase especial para o caso singular - mas não único - das UFs que constituem a região Centro-Oeste.

Apesar de o objetivo deste trabalho ser verificar o grau de heterogeneidade da estrutura industrial existente entre as regióes e, em especial, no caso do Centro-Oeste, é importante esclarecer que não se busca neste texto fazer qualquer análise que tenha por fito destacar que há uma convergência entre a estrutura industrial do Centro-oeste para o padrão prevalecente no estado de São Paulo. São estruturas industriais que apresentam padróes de desenvolvimento distintos, com maturaçôes diferentes e grau de complexidades.

No caso do período da investigação, o intervalo de 1996 a 2016 se justifica, pois foi um momento que a indústria de transformação nacional apresentou uma taxa média de crescimento real de 2,6\% ao ano (a.a.), saltando de $\mathrm{R} \$ 440.828$ milhóes, em 1996; para $\mathrm{R} \$ 752.252$ milhóes, em 2016. ${ }^{2}$ Isto significa que, mesmo apresentando um comportamento cíclico no interstício, ainda assim os setores indústrias brasileiros apresentaram uma trajetória de expansão, a qual sofreu uma reversão cíclica acentuada no período posterior, em especial, impulsionada pela recessão e, em alguns momentos, pela estagnação econômica que contaminou a economia brasileira depois de 2016.

2. Os valores de 1996, 2016 e 2019 estão expressos em valores constantes de 2019. Foi deflacionado pelo Índice Nacional de Preços ao Consumidor (INPC), que é aferido pelo Instituto Brasileiro de Geografia e Estatística (IBGE). 
Para tanto, o método adotado será o histórico-estrutural, ${ }^{3}$ posto que o desenvolvimento é uma categoria histórica que se desdobra, enquanto processo de superação de suas contradiçóes, em uma dimensão dinâmica e, em tempo algum, no âmbito estático-comparativo. Quer dizer, as contradiçóes que afloram em uma economia periférica como a brasileira se desvelam, enquanto resultante síntese, no esgarçamento da tensão existente entre o lado moderno e o lado atrasado, o qual se moldura no esculpir do estilo de desenvolvimento das regióes nacionais.

É neste movimento de síntese que se dará o desenrolar da trama desta investigação, uma vez que o desnudar das contradiçôes em processo acabam rebatendo na estrutura produtiva regional, o que impacta, deste modo, o grau de heterogeneidade estrutural destas economias subdesenvolvidas.

Desde modo, decompõe-se com precisão cirúrgica as estruturas industriais em suas várias partes para, no momento seguinte, reconstruí-la não mais como partes estanques do todo, mas sim como concreto pensado, o qual se objetiva como resultado do movimento de síntese entre as evidências teóricas e empíricas. Como evidências teóricas, adotar-se-á os trabalhos desenvolvidos pelo corpo de pensamento que se originou na Comissão Econômica para a América Latina e o Caribe (CEPAL) e se metamorfoseou na hermenêutica do "capitalismo tardio".

Em relação à estrutura industrial, adotou-se o valor da transformação industrial das empresas industriais (VTI) e o pessoal ocupado (PO) da Pesquisa Industrial Anual - empresa do IBGE. Além destes dados, utilizou-se a lista cadastral de empresas exportadoras do Ministério da Economia. ${ }^{4}$ Para deflacionar os valores do VTI, foram utilizados os deflatores setoriais encontrados no banco de dados do Instituto Brasileiro de Economia (IBRE), da Fundação Getúlio Vargas (FGV). Além disto, os dados sobre exportações da região Centro-Oeste provieram da base de dados da Secretaria de Comércio Exterior (Secex), do Ministério da Economia.

3. Como destacado em Bielschowsky e Torres (2018, p. 22) "El método histórico-estructural se orienta al examen de las transformaciones de mediano y largo plazo de las estructuras productivas y sociales propias del subdesarrollo de América Latina y el Caribe. Se origina en el análisis del subdesarrollo latinoamericano y la problemática de la transición de las estructuras y los patrones de comportamiento económico típicos de la fase agroexportadora ("hacia afuera") a la industrialización y la urbanización (modelo "hacia adentro"), realizado en los primeros años de la (EPAL bajo el mando de Prebisch (CEPAL, 1949 y 1951; Prebisch, 1962 y 1973)".

4. Ver: <https://bit.ly/34zNsqZ>. 
A métrica adotada para capturar o efeito quantitativo da heterogeneidade no tecido industrial, em seus níveis multiescalar e setorial, foi a PT utilizada nas investigaçóes da CEPAL. Entende-se como produtividade média do trabalho industrial, a razão entre o VTI e PO. Por sua vez, o grau da heterogeneidade industrial é aferido pelo coeficiente de variação $(\mathrm{CV})$, um número adimensional que mostra a dispersão dos valores da PT industrial em relação à sua média. Quanto mais os valores se aproximam da média, maior é o grau de homogeneidade da estrutura industrial desta unidade regional. Diversamente, quando mais os valores se distanciam da média, maior é seu o grau de heterogeneidade.

Por sua vez, este trabalho se justifica pela escassez de trabalho que discutem a questão da produtividade média do trabalho dos setores industriais em uma perceptiva regional comparada, ou seja, cotejando algumas experiências regionais ou, então, de UFs vis-à-vis ao estado de São Paulo - que é o centro dinâmico do capitalismo nacional conforme destacado na literatura que versa sobre a questão regional brasileira, em especial, nas investigaçóes de Cano (1978; 2007a; 2007b; 2008) e Cano et al. (2007).

Além disto, é importante ressaltar também que há uma lacuna na literatura econômica de trabalhos que façam uma discussão dos problemas verificados na região Centro-Oeste. Como apontado por Monteiro Neto, Silva e Severian (2020), o setor industrial nacional se espraiou para localidades especificas da região Centro-Oeste demandando, por conseguinte, trabalhos investigativos que discutam como os setores industriais neste espaço regional se integraram, de forma heterogênea, ao eixo de expansão do capital industrial. A compreensão desta questão é de suma importância para o debate sobre a questão regional brasileira, uma vez que a região Centro-Oeste é foco de atuação da II Política Nacional de Desenvolvimento Regional (PNDR), como definido no inciso I do art. 5ำ do Decreto nº 9.810, de 30 de maio de 2019.

Por fim, este trabalho encontra-se decomposto em seis seções. A primeira seção tem por objetivo elaborar a introdução do trabalho, destacando a forma de enunciação do problema de pesquisa, os autores que sustentam a hipótese de estudo, como também as linhas gerais da metodologia e do método, assim como a forma de estruturação do argumento. Na segunda seção, o fito é apresentar uma sistematização das evidências teóricas sobre a heterogeneidade em economias periféricas como a brasileira. 
$\mathrm{Na}$ terceira seção, o núcleo argumentativo refere-se aos fatos estilizados sobre a PT industrial entre as regiốes brasileiras. Por sua vez, a quarta seção foca em mostrar a evolução das exportaçóes de produtos manufaturados da região Centro-Oeste, uma vez que o vetor externo tem um papel central para a incorporaçáo do progresso técnico nas unidades industriais localizadas neste espaço regional. Na seçáo 5, o objetivo é efetuar uma comparação entre a PT industrial setorial por fatores de competividade dos estados que constituem a região Centro-Oeste vis-à-vis ao estado de São Paulo. Por fim, a última seção destaca as observaçôes finais.

\section{UMA SISTEMATIZAÇÃO DAS EVIDÊNCIAS TEÓRICAS SOBRE A HETEROGENEIDADE INDUSTRIAL EM ECONOMIAS PERIFÉRICAS}

A questão dos desequilíbrios regionais brasileiros ganhou expressão no debate nacional com o relatório apresentado por Furtado (1959), no Grupo de Trabalho para o Desenvolvimento do Nordeste (GTDN), ${ }^{5}$ o qual fez uma análise minuciosa do quadro de subdesenvolvimento que se encontrava a economia nordestina. ${ }^{6}$ Como destacou Cano (2007a, p. 23) “Do ponto de vista do diagnóstico da 'Questão Regional', (...) o GTDN é um documento que, à época de sua concepção, constituiu peça excepcional em relação aos demais documentos programáticos regionais”. Para Diniz (2009, p. 237), o GTDN destaca "(...) as razóes do subdesenvolvimento nordestino e cria as bases para a sua superação”. Deste modo, estava lançado as bases para a discussão sobre o problema regional brasileiro, mas com um olhar distante dos cânones ortodoxo da economia regional. ${ }^{7}$

Um ponto importante no debate era compreender porque as economias regionais apresentam estilos de desenvolvimento econômico ${ }^{8}$ diferenciados, dado que, encontravam-se no mesmo espaço nacional. ${ }^{9}$ Em seu trabalho sobre Raizes da concentração industrial em São Paulo, Cano (2007b, p. 265) destacou que “(...) a expansão industrial de São Paulo se deu pelo dinamismo de sua própria economia e não, como se poderia pensar, pela apropriação líquida de recursos provenientes da 'periferia nacional'”.

5. 0 GTDN foi instituído pelo Decreto o 40.554, de 14 de dezembro de 1956.

6. Para maiores detalhes, ver GTND (1959).

7. Para detalhes, ver Diniz (2009) e Pires (2016).

8. Compreende-se a categoria "estilo de desenvolvimento", conforme destacado por Pinto (2000).

9. Para detalhes, ver Oliveira (2003). 
Em outras palavras, os estádios dessemelhantes no padrão de acumulação de capital em nível regional se afloraram em decorrência da forma que se objetivou os desdobramentos do capital no processo histórico de formação da economia nacional, quer dizer, desde a crise do café em 1929, a economia paulista foi se diferenciando no processo de industrialização vis-à-vis às demais regiôes brasileiras.

Esta problemática ficou clara quando Furtado (2003) discutiu a formação econômica brasileira criando, assim, as bases epistemológicas para investigaçóes posteriores que retrataram o caso singular do estado de Sáo Paulo. $\mathrm{O}$ aprofundamento nesta temática foi realizado com maestria por Cano (1978; 2007a; 2007b; 2008) e Cano et al. (2007) quando desvelou em nível regional a centralidade de Sáo Paulo no processo de industrialização brasileiro. ${ }^{10}$ Não obstante, ressalta-se que existiram outras interpretaçóes sobre o processo de industrialização brasileiro que estão bem delineadas no trabalho de Suzigan (2000).

No campo epistemológico do "capitalismo tardio", as interpretaçóes sobre o processo de industrialização nacional que mais se destacaram foram os trabalhos de Aureliano (1981), Cano (2007b), Mello (1991), Silva (1976) e Tavares (1974), que defenderam a tese que o desenvolvimento capitalista nas economias latino-americanas é "(...) determinado primeiramente por fatores internos e secundariamente por fatores externos” (Suzigan, 2000, p. 35). Deste modo, as evidências teóricas sobre a compreensão do papel das forças internas e seu desdobramento nos vetores de tempo e espaço estavam estabelecidas para capturarem as singularidades do estilo de desenvolvimento brasileiro.

Isto posto, o primeiro estágio do processo de industrialização (1930-1955), comandado pelo processo de acumulaçáo de capital proveniente da economia cafeeira, criou as bases objetivas para a internalização das indústrias leves. Apesar disso, o impulso externo teve um papel singular em induzir a penetração do progresso técnico nas estruturas industriais nascentes, visto que o país não tinha capacidade de produzir de forma autônoma as inovaçóes tecnológicas demando, assim, sua importação dos países centrais.

10. No caso de Wilson Cano, pode-se dizer que foi um dos principais pesquisadores entre aqueles que investigaram a questão regional pela ótica do "capitalismo tardio". 
No entanto, depois de 1955, com a industrialização pesada, o padrão de inversão nos setores industriais tornou-se complexo e seletivo, visto que as restriçóes externas se manifestaram de modo mais acentuado, em especial pelo lado do balanço de pagamentos da economia brasileira. Tudo isto criou obstáculos ao avanço do processo de industrialização, essencialmente, por causa da dependência tecnológica e financeira do país em relação às economias centrais.

Sem poder avançar com celeridade pelos estádios superiores do processo de industrialização, por causa das restriçôes externas, então, as inversôes industriais se cristalizaram naquelas regiôes que já apresentavam enraizamentos no processo de acumulação de capital industrial, fato este que acabou moldando a forma de difusão do progresso técnico entre as regiôes. Ou seja, existiram regiốes que aceleraram a modernização de suas estruturas produtivas, pois estavam mais conectadas ao processo de acumulação de capital nacional, e outras que se mantiveram presas aos grilhôes das economias de subsistência e atrasadas.

Esta dualidade entre o moderno e o atrasado tornou-se o traço central de uma economia subdesenvolvida, pois é fruto de um processo de formação econômica que se cristalizou de forma tardia vis-à-vis às economias centrais. ${ }^{11}$ Em outras palavras, que se industrializaram em um momento histórico, no qual os países centrais já tinham desenvolvido e difundido um padrão tecnológico que não poderia ser reproduzido de forma autônoma nas economias periféricas.

Assim, a difusão tecnológica não aconteceu de forma simétrica entre o centro e a periferia e, muito menos, entre as unidades de produção presentes nos setores produtivos das economias subdesenvolvidas. Tudo isso acabou reforçando uma dependência tecnológica entre os países centrais e periféricos que robusteceu ainda mais a rigidez produtiva das economias periféricas.

Deste modo, Furtado (2016, p. 5) apontou que o capitalismo deve ser interpretado como "(...) um processo de difusão do progresso técnico, difusão irregular, comandada pelos interesses das economias criadoras de novas técnicas”. Assim, a difusão irregular do progresso técnico entre as economias centrais e periféricas acaba determinando padróes

11. Para maiores detalhes, ver Oliveira (2003). 
diferenciados na alocação dos recursos naturais e humanos na produção de mercadorias, que acabam impactando, como destacado por Prebisch (2000), na deterioração dos termos de troca entre as economias centrais e periféricas.

Esta contradição, impulsionada pela forma disfuncional de propagação do progresso técnico entre as economias, acabou reforçando ainda mais a dualidade que há nas estruturas produtivas das economias periféricas, posto que amplificou o vetor de modernizaçáo em uma parte da economia, diante do recrudescimento estrutural de economias tradicionais e de subsistência. O principal desdobramento econômico deste movimento foi o alargamento do hiato existente entre o moderno e o atrasado, fato este que direcionou o estilo de desenvolvimento nacional pelos trilhos do subdesenvolvimento - fenômeno independente no tempo e no espaço e que criou certa rigidez para a convergência estrutural entre o lado moderno da economia e sua antítese, que é o lado atrasado.

Deste modo, Furtado (1964, p. 173) destacou que o padrão de acumulação de capital nas economias periféricas “(...) é, portanto, um processo histórico autônomo, e não uma etapa pela qual tenham, necessariamente, passado as economias que já alcançaram grau superior de desenvolvimento".

É neste ponto que Furtado está dialogando, em especial, com Rostow (2010), ${ }^{12}$ que compreende o processo de desenvolvimento econômico como um processo linear de superação de etapas, quer dizer, que se objetiva por meio da passagem de: i) sociedade tradicional; para ii) sociedade que criou as pré-condiçôes para a decolagem; para iii) sociedade da decolagem; para, em seguida, atingir iv) a marcha para a maturidade; e, por fim, v) a sociedade de massas.

Deste modo, Rostow (2010) compreende que é na fase da decolagem que as condiçôes estão postas para a superaçấo da sociedade tradicional para a transformação de uma sociedade moderna. Para Rostow (2010, p. 181), a decolagem é vista como

(...) o intervalo durante o qual a taxa de investimento cresce de tal modo que aumenta o produto real per capita, proporcionando esse aumento inicial transformaçóes radicais na técnica de produção e na disposição dos fluxos de renda que perpetuam a nova escala de investimento e, assim, perpetuam também a tendência crescente do produto per capita.

12. 0 trabalho original de Rostow (1959). 
Este processo linear de transformação das estruturas produtivas apresentado por Rostow (2010) é questionado por Furtado (1964, p. 184), que destacou que "o subdesenvolvimento não constitui uma etapa necessária do processo de formação das economias capitalistas modernas. É em si, um processo particular, resultante da penetração de empresas capitalistas modernas em estruturas arcaicas"

Assim, a penetração de forma assimétrica do progresso técnico em estruturas produtivas subdesenvolvidas é marcada pelo avanço do moderno sobre o atrasado, entretanto, apesar disto, sem forças indutoras suficientes para superar a rigidez naquilo que se refere à incorporação de inovações tecnológicas em sua matriz produtiva. Em outras palavras, parte da economia está presa aos grilhóes das economias de subsistência e tradicionais que, consequentemente, são refratarias ao avanço da modernização de suas estruturas produtivas. ${ }^{13}$

Deste modo, Furtado (2006, p. 204) destacou que

O crescimento de uma economia desenvolvida é, portanto, principalmente um problema de acumulação de novos conhecimentos científicos e de progressos na aplicação desses conhecimentos. O crescimento de economias subdesenvolvidas é sobretudo um processo de assimilação da técnica prevalecente na época.

Quer dizer, a forma que o incremento do progresso técnico se cristalizou nas economias periféricas, por meio da incorporação e difusão de conhecimento cientifico aplicado elaborado nos países centrais, moldou o método que as inovaçóes tecnológicas - naquilo que se refere à incorporação de novos processos de produção, na criação de novos produtos, nas conquistas de novas fontes de matérias-primas, na abertura de novos mercados como definidos em Schumpeter $(2017)^{14}$ - se enraizaram

13. Na interpretação de Lopes (2016, p. 120), "Do ponto de vista da estrutura produtiva (condições de oferta), demonstra-se que Furtado reconheceu o progresso técnico como a mera difusão dos métodos produtivos criados nas economias centrais". 14. Schumpeter (2017, p. 117, grifo nosso) destacou que "O capitalismo é, por natureza, uma forma ou método de transformação econômica e não só não é, como não pode ser estacionário. E o caráter evolucionário do processo capitalista não se deve meramente ao fato de a vida econômica transcorrer em um ambiente social e natural que se transforma incessantemente e cujas transformações alteram os dados da ação econômica; esse fato é importante e essas mudanças (guerras, revoluções e assim por diante) geralmente condicionam as mutações industriais, mas não são a sua principal causa motriz. Esse caráter evolucionário também não se deve a um crescimento quase automático da população e do capital ou aos caprichos dos sistemas monetários, que tampouco figuram entre as suas principais causas motrizes. 0 impulso fundamental que põe e mantém em movimento a máquina capitalista é dado pelos novos bens de consumo, os novos métodos de produção ou transporte, os novos mercados e as novas formas de organização industrial criadas pela empresa capitalista". 
nas estruturas produtivas das economias periféricas, em particular, por reforçarem ainda mais a dependência tecnológica das grandes empresas multinacionais e, mais recentemente, das transnacionais.

É por meio desta disfuncionalidade no processo de formação das estruturas produtivas regionais que se objetiva o problema da heterogeneidade estrutural e produtiva. Para Pinto (2000, p. 575), "a capacidade de irradiação ou impulsionamento do 'setor moderno' revelou-se, para dizer o mínimo, muito menor do que a esperada. Assim sendo, mais do que um processo para a 'homogeneização' da estrutura global, perfila-se um aprofundamento de sua heterogeneidade".

Concisamente, o avanço do progresso técnico nas economias periféricas, que se objetivou por meio do incremento da PT, reforçou, ainda mais, a dualidade da economia, uma vez que a internalização da inovação tecnológica nos países periféricos decorreu, sobremaneira, pela difusão reflexa e dependente dos conhecimentos e técnicas desenvolvidas nos países centrais, os quais estavam condicionados para atenderem as demandas das empresas que atuavam em estruturas industriais maduras, modernas e que se encontravam na fronteira tecnológica mundial. ${ }^{15}$

Para Cimoli et al. (2005, p. 11)

a concentração do progresso técnico criou uma estrutura de produção segmentada, onde se podiam distinguir pelo menos três estratos. No estrato produtivo mais alto - o polo moderno -, encontravam-se as atividades de exportação, industrial e de serviços, que funcionavam com níveis de produtividade semelhantes à média das economias mais desenvolvidas. No estrato inferior - o primitivo -, encontravam-se os setores mais retardatários cuja produtividade não era muito diferente da época colonial.

Estes traços do subdesenvolvimento foram reforçados, em especial, com a tentativa de internalização dos setores superiores da estrutura industrial das economias periféricas, salto mortal da industrialização leve para a pesada, uma vez que as contradiçóes impostas

15. Como bem destacou Lopes (2016, p. 124) "Sua ideia é que o progresso técnico tende a ser recorrente e disseminar-se, nas nações desenvolvidas, de forma mais rápida e eficaz. Já nas economias periféricas, a inventividade do ser humano reduz-se apenas à difusão de técnicas e não a sua criação". 
pelo estilo de desenvolvimento de uma economia periférica ${ }^{16}$ acabaram determinando restriçôes no balanço de pagamentos (crises cambiais recorrentes) que criaram óbices para o avanço do processo de industrialização destas economias. Este fato potencializou, ainda mais, o grau de heterogeneidade do tecido industrial, em especial, da economia brasileira. Assim, Porcile, Yamila e Catela $(2012$, p. 2) salientaram que

o desenvolvimento, na visão estruturalista, é concebido como um processo impulsionado pelo progresso técnico e marcado por desequilíbrios que redefinem a estrutura produtiva. Mas este processo é assimétrico, ocorre de forma desigual entre regióes e setores, concentrando a inovação em partes localizadas do sistema. Na periferia o progresso técnico não se difunde em forma homogênea, sendo absorvido somente em certas atividades, principalmente nas vinculadas à exportação, permanecendo inalterada a estrutura produtiva restante.

Por fim, Bielschowsky e Torres (2018, p. 355) destacaram a seguinte passagem relativa os problemas enfrentados pelas economias periféricas:

O primeiro é o atraso relativo, ou hiato externo, que reflete as assimetrias nas capacidades tecnológicas da região em relação à fronteira internacional. A velocidade com que as economias desenvolvidas inovam e disseminam a tecnologia em seu tecido produtivo excede a velocidade com que os países da América Latina e do Caribe são capazes de absorver, imitar, adaptar e inovar com base nas melhores práticas internacionais.

É no contexto deste debate que os trabalhos de Kupfer e Rocha (2004), Naciones Unidas (2005), Bárcena et al. (2010), Squeff e Nogueira, (2013) e Cavalcante e De Negri (2014), e Pires (2016) tentaram compreender um pouco mais a complexidade, as regularidades e as uniformidades do fenômeno da heterogeneidade industrial brasileira. $\mathrm{O}$ argumento central, que perpassa todos os trabalhos, é que o problema da heterogeneidade da industrial brasileira é atávico e, por isto, não é superado com o processo de modernização dos setores industriais brasileiros.

Tudo isto reforça a tese de Furtado que o subdesenvolvimento não é uma etapa do desenvolvimento, mas sim um sério problema estrutural que náo é superado pelo simples movimentar das forças de mercado como derivados dos modelos hermenêuticos enraizados nos cânones ortodoxos.

16. Para detalhes, ver Draibe (1985), Mello (1991), Bielschowsky (1996) e Rodríguez (2009). 
Como as implicaçóes do subdesenvolvimento nas estruturas industriais de economias periféricas é abstruso, pois se apresenta de forma multifacetada para a sua compreensão racional. Então, a próxima seção tem por fito lançar um olhar não para a sua dimensão setorial, mas sim para a dimensão regional do fenômeno. Quer dizer, compreender como se está objetivando a heterogeneidade industrial entre as regiões brasileiras no período de 1996 a 2016.

\section{FATOS ESTILIZADOS SOBRE A PT INDUSTRIAL ENTRE AS REGIÕES BRASILEIRAS}

Uma questão importante para se destacar na estrutura industrial das regióes brasileiras refere-se ao problema da heterogeneidade que há entre elas. ${ }^{17}$ Este fato decorre da forma que o processo de industrialização nacional (Modelo de Substituição de Importações) espraiou pelo território nacional, concentrando-se em pontos específicos do espaço, particularmente entre 1930 e 1980 , reforçando, por conseguinte, os desequilíbrios inter-regionais.

Entre 1930 e 1970, grande parte do setor industrial nacional concentrou-se no estado de São Paulo, porém, com as políticas de desconcentração regional impulsionadas pelo II PND (1974-1979), houve um deslocamento produtivo para as localidades no interior do estado de São Paulo, como também para regiôes periféricas do capitalismo nacional.

Segundo dados da FGV, a participação relativa do PIB do Sudeste - Minas Gerais, Espírito Santo, Rio de Janeiro e São Paulo - em 1959 era de 63,0\%. A região Sul detinha 18,2\%; Norte tinha uma participação de 2,0\%; o Nordeste de 14,4\%; e o Centro-Oeste de 2,4\%. Em 1970, pelos dados do IBGE, o Sudeste detinha 65,5\% do PIB brasileiro - tendo, Minas Gerais 8,3\%; Espírito Santo 1,2\%; Rio de Janeiro 15,4\% e São Paulo 39,2\% -, o Sul detinha 16,7\%; o Norte 2,2\%; Nordeste 11,7\%; e, por fim, o Centro-Oeste 3,9\%. ${ }^{18}$

17. Como destacou Monteiro Neto, Silva e Severian (2020, p. 117) "O acelerado crescimento das atividades produtivas na região Sudeste - com o epicentro em São Paulo - levou, do ponto de vista do país como um todo, a um nível bastante elevado de desigualdade regional da atividade econômica. Com isso, o produto interno bruto (PIB) da região Sudeste atingiu um máximo de 65,5\% do total nacional em 1970 e 54,0\% em 2015".

18. Para detalhes, ver Monteiro Neto $(2005$, p. 92). 
Por sua vez, o processo de desconcentraçáo industrial das regióes brasileiras perdeu impulso nos anos 1980, quando a crise fiscal e financeira do governo federal desestruturou as políticas de desconcentraçáo do investimento produtivo regional, visto que a prioridade se tornou a estabilizaçáo da economia por meio de sucessivos planos de estabilização monetária.

Entre 1986 e 1994, foram implementados os Planos Cruzado I (fevereiro de 1986) e II (novembro de 1986), Bresser (1987), Verão (1988), Collor I (1990) e II (1991), e Plano Real (1994). Estes planos tiveram impactos significativos nas decisões de investimentos realizadas nos setores industriais, posto que as incertezas sobre o porvir da econômica impactaram negativamente na formação das expectativas dos agentes econômicos e na libertaçáo do seu animal spirit keynesiano. O principal reflexo disto tudo foi que os anos de 1980 foram grifados como a década perdida para a economia nacional, bem como para o setor industrial.

No caso regional, Cano (2008, p. 227) destacou que o processo dedesconcentração industrial no período pós-1970 deve ser analisado com certa cautela, visto que

a desconcentração industrial prosseguiu, porém, em ritmo mais vagaroso, com São Paulo perdendo 3,2 pontos percentuais no VTI nacional do setor. Contudo, há que advertir o leitor que as informaçóes que cobrem o período - principalmente a partir de 1985, com o último Censo Industrial - obscurecem a análise do processo. Dela infere-se que, se havia uma 'tendência' desconcentradora entre 1970 e 1985, ela já não era táo clara nos dados que compreendiam os anos de 1985-1989.

Estes argumentos foram reforçados por Caiado (2002, p. 187), que destacou

o abandono do modelo de "Estado desenvolvimentista", desde o final dos anos 80 e, sobretudo, a implantação do receituário neoliberal, na década de 90, interromperam o processo de integração do mercado nacional e tornaram mais seletiva a localizaçáo das atividades mais dinâmicas, do ponto de vista setorial e espacial. Reduziram ainda mais a solidariedade produtiva inter-regional, contribuíram para o estancamento da desconcentração e sua reversão em divisões industriais de maior complexidade tecnológica e geraram poucos efeitos de estímulo, fortes efeitos de bloqueio e até de destruição sobre a estrutura produtiva regional brasileira.

Com o aprofundamento dos desequilíbrios macroeconômicos do Estado brasileiro nos anos de 1990, por meio do agravamento da crise da dívida externa, um conjunto de reformas e desregulamentaçôes foram impostas ao governo federal no contexto do 
processo de renegociação da dívida externa, quer dizer, pelo Plano Brady (1992-1994). Este conjunto de reformas teve por objetivo adotar no Brasil os postulados determinados pelo Consenso de Washington. ${ }^{19}$

Entre as reformas adotadas, a liberalização financeira, produtiva e a desregulamentação da economia tiveram o objetivo de integrar o mercado nacional ao mercado internacional, o que ampliou, assim, a oferta de produtos externos no mercado nacional. ${ }^{20}$ Como destacado por Ribeiro e Markwald (2008, p. 353),

a década de 1990 testemunhou uma importante transformação da relação do Brasil com a economia mundial. O trauma da crise econômica que atravessou a 'década perdida' dos anos 1980 e a percepção de que o processo de substituição de importaçôes havia esgotado suas possibilidades levaram à adoção de medidas liberalizantes, entre as quais duas se destacaram: a abertura comercial e a liberalização dos fluxos de capitais. O diagnóstico subjacente era o de que a economia brasileira precisava se integrar, de forma mais profunda, à economia mundial, privilegiando os mecanismos de mercado e abandonando medidas amplamente utilizadas no passado, como os subsídios às exportaçóes e os controles seletivos sobre as importações. A ideia era estimular os ganhos de eficiência e produtividade por meio da concorrência com produtos importados e, também, do acesso a bens de capital e insumos produzidos no exterior com maior conteúdo tecnológico.

As transformaçóes que aconteceram na economia nacional, depois dos anos 1990, suscitaram um novo debate sobre o processo de concentração e desconcentração das atividades industriais no tecido regional brasileiro. Vários trabalhos foram desenvolvidos sobre esta temática tentando compreender, um pouco mais, a complexidade do fenômeno da desconcentração industrial. Entre eles, destacam-se os estudos Diniz (1993), Pacheco (1996), e Monteiro Neto, Silva e Severian (2020).

No contexto regional, o processo de globalização acabou impulsionando a desregulamentação e liberalização dos mercados e estimulando a competição, de forma exacerbada, entre as empresas internacionais, nacionais e regionais. Para Santos (2020),

19. Para detalhes, ver Kuczynski e Williamson (2004).

20. Como apontado por Prates (1999, p. 56), as principais diretrizes do Consenso de Washington para os países da América Latina foram as seguintes: "os países latino-americanos deveriam implementar um conjunto de reformas com o objetivo de eliminar as distorções introduzidas pela estratégia de desenvolvimento anterior. Entre as reformas, destacavam-se a eliminação das regulamentações estatais sobre os mercados domésticos, a privatização, a liberalização financeira interna e a abertura externa das economias. As aberturas comercial e financeira das economias constituíam peças centrais para a mudança na estratégia de desenvolvimento - de inward-oriented para outward-oriented". 
os elementos motores que serviram de vetores deste processo de modernização foram estabelecidos no plano dos

(...) egoísmos locais ou regionais exacerbados, justificados pela necessidade de defesa das condiçóes de sobrevivência regional, mesmo que isto tenha de se dar à custa da ideia de integridade nacional. Esse caldo de cultura pode levar à quebra da solidariedade nacional e conduzir a uma fragmentaçáo do território e da sociedade. (Santos, 2020, p. 94).

É neste contexto de integraçáo das regióes aos mercados internacionais e da potencialização da concorrência destas localidades por investimentos produtivos que Pacheco (1996) destacou o rompimento do pacto federativo de solidariedade inter-regional, em especial por causa da disputa por investimentos industriais - essencialmente aqueles oriundos dos países centrais. Sem uma economia nacional pulsante, por causa dos desajustes macroeconômicos, entâo, coube ao vetor externo um papel mais ativo como indutor do progresso técnico reforçando, assim, a marcha da fragmentação da nação.

quero dizer que há desconcentração sim, mas que ela se manifesta mais sob a forma de uma flagrante fragmentação da economia nacional, do que no crescimento solidário das regióes, com acréscimo de capacidade produtiva nos principais espaços econômicos da Nação. Isto significa que a trajetória da economia brasileira nos anos 80 e 90 sobredeterminou as possibilidades regionais, circunscrevendo-as, no que tinha de dinâmico, aos poucos incentivos ao incremento da atividade exportadora. Pacheco (1996, p. 128).

Por outro lado, Diniz (1993) argumentou que houve um movimento de "desconcentração concentrada" do setor industrial no espaço regional brasileiro. Pelo lado da desconcentraçáo, os setores industriais deslocaram-se do centro dinâmico urbano e industrial, que é a cidade de Sáo Paulo, e espraiaram de forma concentrada para o interior do estado definindo, por conseguinte, um vetor de expansão do capital industrial que se cristalizou no polígono entre Belo Horizonte-Uberlândia-Londrina/MaringáPortoAlegre-Florianópolis-São José dos Campos-Belo Horizonte.

Em pesquisa recente, Monteiro Neto, Silva e Severian (2020) resgataram a metodologia desenvolvida por Diniz (1993) aplicando-a, com algumas modificaçóes em termos de escala sub-regional, para compreender o perfil e dinâmica das desigualdades regionais do Brasil em territórios industriais relevantes. As principais conclusóes apresentadas pelos autores foram as seguintes: 
No primeiro grupo, estão mais associadas às externalidades das AIRs consolidadas nas áreas mais industrializadas do Sudeste e do Sul. No segundo grupo, revelam a formação mais incipiente de territórios industriais que se desenvolveram na última década por impulsos da expansão da renda e do mercado interno regional nas regióes Nordeste, Centro-Oeste e Norte (Monteiro Neto, Silva e Severian, 2020, p. 148).

É neste contexto de controvérsia sobre a questão da desconcentraçáo industrial que se estabeleceu o debate sobre o espraiamento e a difusão do progresso técnico entre os setores industriais e regionais brasileiros. É por meio dos investimentos de modernização que as estruturas produtivas, em especial a industrial, foram se transformando; porém, vinculadas ou não com os setores modernos da economia nacional e internacional. Neste sentido, o avanço do progresso técnico pelo espaço territorial acabou aprofundando o grau de heterogeneidade da estrutura industrial das regiôes brasileiras.

Isto ficou claro em Kupfer e Rocha (2004, p. 39), ao destacarem que "a modernização da indústria brasileira caracterizou-se por um intenso aumento da heterogeneidade estrutural”. Essas mesmas conclusóes foram realçadas no trabalho de Porcile, Yamila e Catela (2012, p. 17), que destacaram a "elevada heterogeneidade que encontramos dentro da indústria de transformação brasileira”.

\section{GRÁFICO 1}

Produtividade média do trabalho dos setores industriais brasileiros (1996-2016)

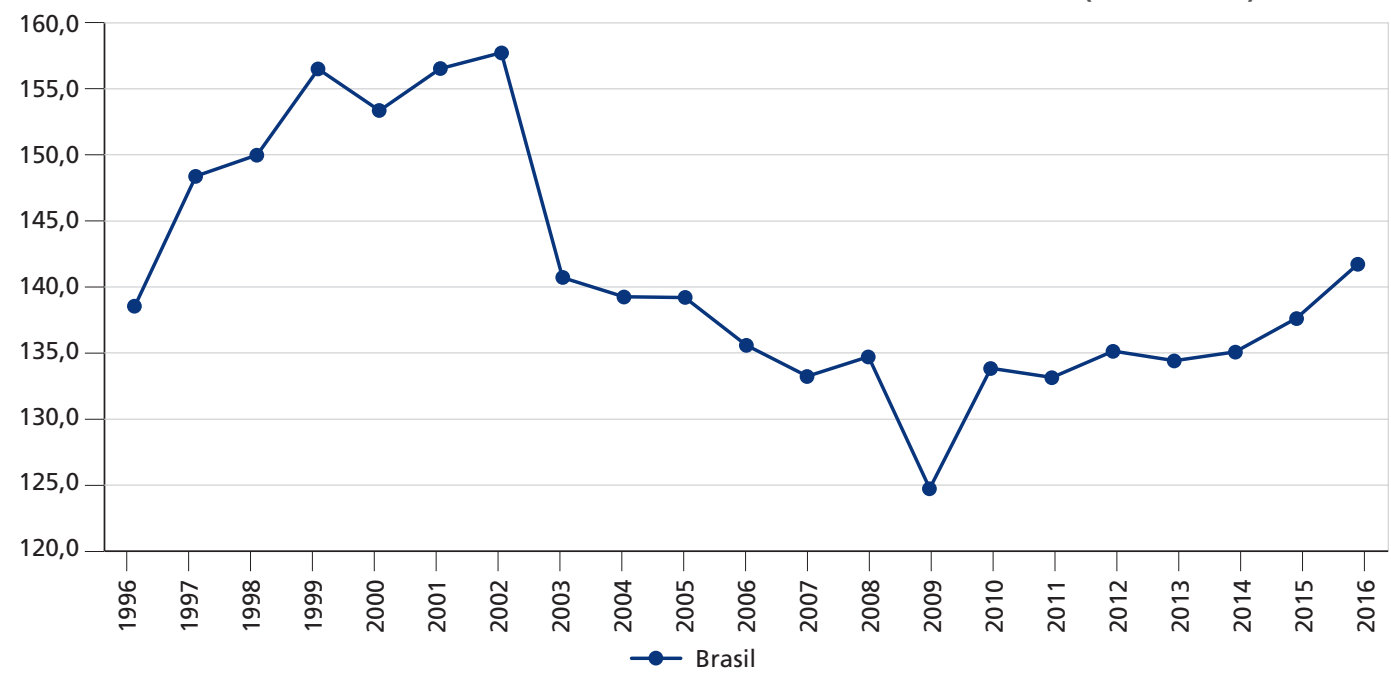

Fonte: Pesquisa Industrial Anual - Empresa do IBGE. 
Uma das multifaces que o processo de modernização da estrutura industrial nacional pode se apresentar à consciência do investigador em sua complexidade integral é por intermédio do avanço do progresso técnico nas estruturas produtivas, a qual pode ser aferida enquanto proxy pela produtividade média do trabalho. ${ }^{21}$ Como destacado no gráfico 1, no período de 1996 a 1999 há um incremento na PT industrial brasileira, porém, com a crise cambial de $1999,{ }^{22}$ que determinou uma alteração no regime monetário (câmbio flutuante, metas de inflação e superávit fiscal), observa-se que o vigor da produtividade média do trabalho vai perdendo, aos poucos, força em associação com o ajuste econômico conservador que foi efetuado na economia nacional.

Deste modo, nota-se que há uma desaceleração na produtividade média do trabalho; contudo, acentuando ainda mais no período da crise internacional dos anos de 2007 a 2009. No entanto, entre 2009 e 2016, constatou-se um suave crescimento na produtividade média do trabalho industrial nacional, todavia aquém dos valores verificados antes da crise cambial de 1999.

No entanto, é importante ressaltar que este indicador demostrou o comportamento agregado da economia nacional, o que não permitiu destacar os fatos que se cristalizaram nas múltiplas escalas regionais. Ou melhor, quando se desagrega este indicador em vetores multiescalares regionais, nota-se que a economia brasileira é marcada, como observou Porcile, Yamila e Catela (2012, p. 2), por "diferenças de produtividade do trabalho [que] são muito elevadas".

21. A métrica adotada nesta investigação para aferir a heterogeneidade da estrutura industrial das regiões brasileiras, no período de 1996 a 2016, foi a produtividade média do trabalho, a qual foi proposta nos trabalhos desenvolvidos pela CEPAL. 22. Como destacaram Ribeiro e Markwald (2008, p. 354), os impactos externos no balanço de pagamentos brasileiro provocaram o seguinte fenômeno em 1999: "a deterioração das contas externas foi agravada por uma sequência de crises externas. De fato, no segundo semestre de 1997, eclodiu a crise nos países do leste asiático e, um ano depois, em agosto de 1998, ocorreu o default da Rússia. Esses eventos aceleraram a fuga de capitais no Brasil e precipitaram a crise cambial que culminou, em janeiro de 1999, com a adoção de um regime de livre flutuação do câmbio e a abrupta depreciação da moeda". 
GRÁFICO 2

Produtividade média do trabalho dos setores industriais brasileiros - grandes regiões (1996-2016)

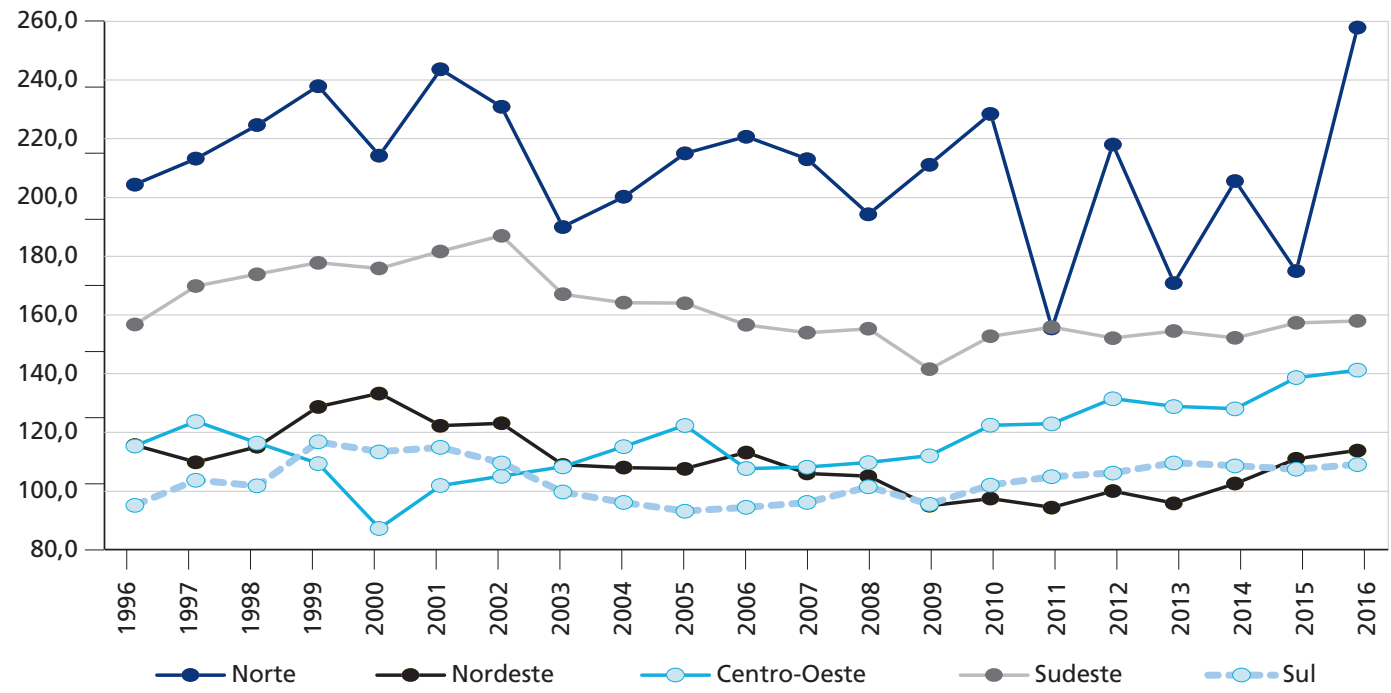

Fonte: Pesquisa Industrial Anual - Empresa do IBGE.

Elaboração do autor.

No caso dos setores industriais regionais, um fato que merece destaque refere-se às diferenças que há entre as produtividades médias dos setores industriais das regiôes brasileiras. Distingue-se, no gráfico 2, que a produtividade industrial média da região Norte é superior às demais regióes. A região Sudeste, que concentra grande parte do parque industrial nacional, ${ }^{23}$ encontra-se na segunda posição, mais seguido, com alternância de posições, pelas regióes Centro-Oeste, Sul e Nordeste.

23. Ao discutir o caso da indústria paulista Cano et al. (2016) faz a seguinte observação: "A indústria de transformação estadual foi a mais duramente atingida do país, tanto durante a década de 1980 quanto, principalmente, a partir da introdução das políticas neoliberais do período seguinte, com fechamento e desnacionalização de plantas, mutilação de cadeias produtivas, inibição do investimento e forte redução no emprego. A guerra fiscal interestadual foi responsável por parte expressiva da desconcentração industrial do período, notadamente da automobilística e de produtos eletrônicos e nos ramos têxtil, de calçados e de vestuário, em que a informalização e o trabalho barato não raro predominaram. 0 crescimento industrial foi medíocre, tanto assim que nossa estrutura produtiva regrediu, com o setor agro aumentando sua participação no PIB, e o industrial, diminuindo-a. Contudo, a perda de participação paulista no total nacional, em vários segmentos produtivos, a nosso juízo, é mais um efeito estatístico, pois resulta não de um maior crescimento periférico e sim de uma queda paulista acentuadamente maior do que a queda verificada na periferia. 0 mercado interno foi débil, mesmo para o parco crescimento do período, tendo sido externo o principal escoadouro: entre 1989 e 2004, a participação das exportações industriais paulistas passam de 17\% para $46 \%$ de seu PIB setorial". 
Assim, é importante ressaltar que a taxa de crescimento da produtividade média do trabalho industrial nacional foi de 0,1\% a.a., entre os anos de 1996 e 2016. No caso da região Norte, a taxa média de crescimento da PT industrial apresentou um crescimento de $1,2 \%$ a.a., quer dizer, pouco mais que o décuplo daquela aferida para a média nacional. Ao compararmos a Sudeste, centro do capitalismo industrial e financeiro nacional, com a regiáo Norte, sua taxa de crescimento do trabalho industrial foi cerca de trinta vezes menor. Entretanto, o trabalho de Cavalcante e De Negri (2014, p. 163) argumenta que este elevado nível da produtividade média do trabalho industrial na região Norte, em especial no estado do Amazonas que concentra grande parte dos setores industriais da regiáo por causa da Zona Franca de Manaus (ZFM), pode ser explicado pela:

Além disso, a maior presença de setores mais dinâmicos (como a fabricação de equipamentos de informática, produtos eletrônicos e ópticos) ou mais intensivos em capital (como a fabricação de produtos químicos) tende a elevar os níveis médios de produtividade da indústria em estados como o Amazonas e a Bahia. Por outro lado, estados cuja indústria é mais tradicional e menos intensiva em capital ou cujo parque industrial é mais antigo têm menores níveis de produtividade do trabalho. Isso provavelmente ajuda a explicar por que Sáo Paulo ocupa apenas a oitava posição no ranking de produtividade do trabalho na indústria.

Como é destacado no gráfico 2, observa-se que há um declínio na produtividade média do trabalho dos setores industriais que constituem a região Sudeste desde 2002, o qual se acentuou no período da crise de liquidez, entre 2007 e 2009. Mesmo existindo uma ligeira recuperação depois de 2009, ainda assim os valores mantiveram-se oscilando na faixa do valor observado em 2006, antes da crise de liquidez internacional; porém, sem se acentuarem em decorrência do período recessivo vivenciado pela economia nacional, depois de 2014.

Por outro lado, a taxa de crescimento da produtividade média do trabalho industrial da região Centro-Oeste apresentou uma expansão significativa entre as regiôes nacionais no período entre 1996 e 2016 (1\% a.a.). Isto significa que a incorporação de progresso técnico nos setores industriais centro-oestinos, além de incrementarem o produto industrial da regiáo, impulsionou o crescimento da mesma em um ritmo superior ao daquele verificado para a média nacional, e pouco mais que vinte e seis vezes daquela aferida para a regiáo Sudeste. 
Uma possibilidade para a explicação desta expansão da produtividade média do trabalho industrial da região Centro-Oeste refere-se à articulação que os setores industriais locais tiveram com a dinâmica posta pelos mercados internacionais. Segundo Torres Filho e Puga (2009, p. 74), ${ }^{24}$

graças a esse cenário externo, o comércio exterior brasileiro atravessou, entre 1998 e 2008, seu ciclo de ouro, em mais de 50 anos. Nessa última década, a corrente de comércio passou de 13,0\%, em 1998, para mais de 23,0\% do PIB, o nível mais elevado registrado desde 1958. Isso se deveu tanto à expansão das exportaçôes, que cresceram a quase $12,0 \%$ ao ano, quanto das importaçóes, que aumentaram 9,6\% ao ano.

Este desempenho favorável do vetor externo do Centro-Oeste vis-à-vis as demais regiôes brasileiras, também foi destacada no trabalho de Pires (2019, p. 25) que fez a seguinte observação:

(...) em termos de exportaçóes macrorregionais, a região Sudeste, que representa o maior grau de industrialização entre as regiôes nacionais, foi aquela com a maior participação na pauta de exportaçáo nacional no período de 1990 a 2016. Em seguida, veio a regiáo Sul, com o segundo maior grau de industrialização regional. Na terceira posição, em 2016, estava a região Centro-Oeste - que, no início dos anos 1990, chegou a manifestar a menor participaçáo entre todas as regióes exportadoras nacionais.

Em síntese, os dados apontam que há uma forte heterogeneidade na produtividade média do trabalho industrial em nível regional. Isto significa que o progresso técnico se difundiu de forma assimétrica entre as UFs. Quer dizer, em algumas UFs, os agentes econômicos incorporaram em suas empresas novos conhecimentos de ciências e tecnologias e modernizaram seus sistemas de produção, ao passo que, outros agentes econômicos ainda mantiveram arraigados em processos pretéritos e tradicionais de fabricação de mercadorias. Este diferencial de incorporação do progresso técnico entre os agentes econômicos acabou reforçando, ainda mais, a heterogeneidade industrial entre as UFs.

24. Siqueira $(2013$, p. 79$)$ alega que "o dinamismo da região Centro-Oeste está claramente vinculado ao aprofundamento da especialização do país em commodities agrícolas e minerais e à expansão da fronteira de recursos naturais". 
GRÁFICO 3

CV: produtividade média do trabalho dos setores industriais, segundo UFs - grandes regiões (1996-2016)

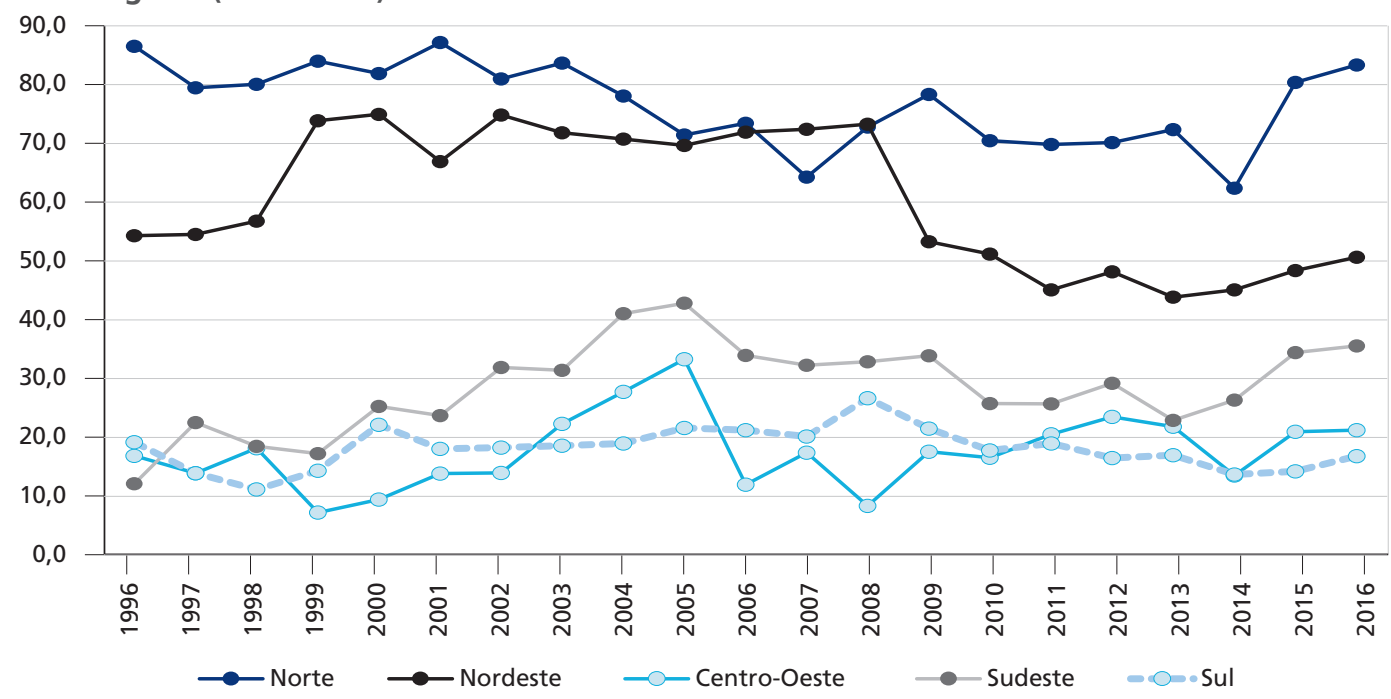

Fonte: Pesquisa Industrial Anual - Empresa do IBGE. Elaboração do autor.

Como é evidenciado no gráfico 3, os coeficientes de variação da produtividade média do trabalho industrial apontam que há uma forte heterogeneidade nos setores industriais dos estados que formam as regióes Norte e Nordeste. Isto aconteceu porque as empresas que fazem a tessitura do tecido industrial destas regióes apresentaram diferenciais expressivos na incorporação do progresso técnico em suas plantas industriais, sendo que, uma parte está fortemente conectada com as cadeias produtivas nacionais e internacionais. E, por isto, as empresas acabam incorporando novas tecnologias em seus processos produtivos, ao passo que, outras instituiçôes ainda se agarram em tecnologias tradicionais que incorporam pouca inovação tecnológica em suas unidades de produção.

Por sua vez, no caso das UFs das regióes Sudeste, Centro-Oeste e Sul, observa-se que a dispersão da produtividade média do trabalho dos setores industriais apresenta um grau maior de homogeneidade vis-à-vis aquelas apuradas para as regióes Norte e Nordeste. Isto é um indicativo de que a difusão do progresso técnico, entre as unidades de produção que constituem estes espaços regionais, não apresenta disparidades expressivas como aquelas percebidas para os estados das regióes Norte e Nordeste. 
TABELA 1

Produtividade média do trabalho dos setores industriais, segundo UFs (Em \%)

\begin{tabular}{|c|c|c|c|c|c|}
\hline UF & 1996 & 2001 & 2006 & 2011 & 2016 \\
\hline Acre & 53,8 & 37,1 & 42,5 & 57,7 & 76,6 \\
\hline Alagoas & 101,5 & 59,7 & 45,2 & 54,7 & 52,7 \\
\hline Amapá & 296,6 & 132,8 & 159,4 & 97,1 & 62,7 \\
\hline Amazonas & 267,5 & 345,0 & 304,4 & 238,5 & 344,7 \\
\hline Bahia & 239,7 & 300,0 & 273,0 & 182,3 & 216,7 \\
\hline Ceará & 65,5 & 55,8 & 52,9 & 58,6 & 69,9 \\
\hline Distrito Federal & 87,0 & 81,6 & 89,5 & 103,5 & 96,5 \\
\hline Espírito Santo & 181,0 & 242,3 & 239,5 & 188,0 & 200,4 \\
\hline Goiás & 112,7 & 100,6 & 103,6 & 107,6 & 133,3 \\
\hline Maranhão & 137,6 & 216,2 & 192,8 & 101,3 & 136,4 \\
\hline Mato Grosso & 121,4 & 115,1 & 117,3 & 159,4 & 156,3 \\
\hline Mato Grosso do Sul & 131,8 & 98,1 & 115,1 & 132,6 & 159,1 \\
\hline Minas Gerais & 137,2 & 164,0 & 131,0 & 140,9 & 133,0 \\
\hline Pará & 181,9 & 235,6 & 188,4 & 85,3 & 279,3 \\
\hline Paraíba & 61,7 & 64,3 & 47,4 & 58,9 & 60,5 \\
\hline Paraná & 115,7 & 132,1 & 116,3 & 123,4 & 122,0 \\
\hline Pernambuco & 97,3 & 78,4 & 64,0 & 73,5 & 98,0 \\
\hline Piauí & 50,9 & 85,2 & 75,3 & 77,9 & 67,1 \\
\hline Rio de Janeiro & 147,5 & 262,5 & 260,7 & 239,5 & 280,6 \\
\hline Rio Grande do Norte & 100,0 & 112,4 & 88,9 & 88,3 & 116,3 \\
\hline Rio Grande do Sul & 93,2 & 120,4 & 92,4 & 106,5 & 117,4 \\
\hline Rondônia & 37,4 & 58,2 & 76,4 & 83,9 & 89,5 \\
\hline Roraima & 25,0 & 28,6 & 70,3 & 37,6 & 51,8 \\
\hline Santa Catarina & 79,1 & 91,8 & 76,2 & 83,9 & 88,1 \\
\hline São Paulo & 162,4 & 171,2 & 143,8 & 145,5 & 144,3 \\
\hline Sergipe & 89,1 & 166,5 & 167,4 & 83,7 & 93,4 \\
\hline Tocantins & 65,3 & 102,1 & 60,2 & 65,1 & 89,9 \\
\hline Média & 120,0 & 135,5 & 125,7 & 110,2 & 131,0 \\
\hline Desvio-Padrão & 67,4 & 82,7 & 74,5 & 53,4 & 75,0 \\
\hline Coeficiente variação & 56,2 & 61,1 & 59,3 & 48,4 & 57,2 \\
\hline
\end{tabular}

Fonte: Pesquisa Industrial Anual - Empresa do IBGE.

Elaboração do autor.

Esta evidência empírica sobre a heterogeneidade da estrutura industrial entre as UFs fica mais indubitável quando se observa a tabela 1 . Há um número significativo de UFs que apresentam uma produtividade média do trabalho industrial aquém daquela 
aferida para a média nacional. Por exemplo: entre os anos de 1996 e 2016, a participação das UFs que apresentaram a PT industrial superior àquela aferida para a média nacional foi, respectivamente, 41\% (1996), 33\% (2001), 37\% (2006), 33\% (2011) e $41 \%$ (2016); ou seja, das 27 UFs, poucas conseguiram apresentar uma produtividade média do trabalho industrial superior à média nacional.

Grande parte das UFs que apresentaram produtividade média do trabalho industrial aquém daquela verificada para a média nacional estavam localizadas nas regiôes Nordeste, com maior concentração, seguida pelas UFs das regióes Norte, Sul e Centro-Oeste. Por outro lado, observa-se que os estados que constituem a região Sudeste apresentaram uma produtividade média do trabalho superior àquela apurada para a média nacional, mostrando, assim, que há um grau maior de homogeneidade em seu tecido industrial naquilo que se refere à difusão do progresso técnico.

\section{GRÁFICO 4}

Razão entre a produtividade média industrial do estado de São Paulo vis-à-vis às principais UFs

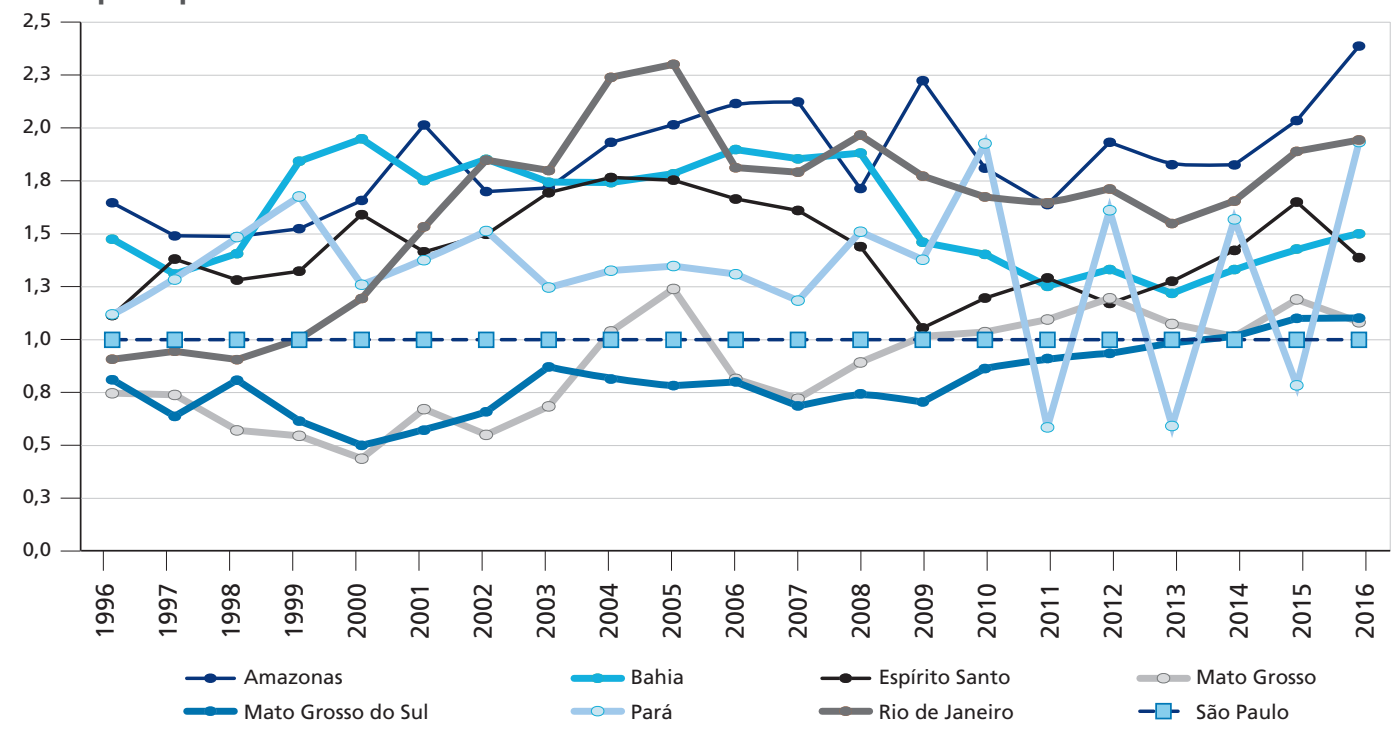

Fonte: Pesquisa Industrial Anual - Empresa do IBGE Elaboração do autor.

Quando se destaca a razáo entre a produtividade média do trabalho dos setores industriais do estado de São Paulo vis-à-vis as demais UFs (gráfico 4), observa-se que as UFs que exibiram maior produtividade média industrial, quando comparadas com o estado de Sáo Paulo, foram aquelas que apresentaram estruturas industriais fortemente 
enraizadas em suas vantagens comparativas, quer dizer, em setores baseados em recursos naturais - como fabricação de produtos alimentares e bebidas, extração e fabricação de produtos minerais metálicos e não metálicos, extração e fabricação de produtos de petróleos, derivados e biocombustíveis e celulose, fabricação de produtos de celulose e papel -, como também por projetos de incentivo e benefícios fiscais, como aqueles encontrados na ZFM.

Por fim, o foco central da investigaçăo é compreender o caso especifico - mas não único - da regiáo Centro-Oeste naquilo que se refere ao grau de heterogeneidade da estrutura industrial das UFs que constituem este espaço regional vis-à-vis ao estado de Sáo Paulo. Para tanto, a seção 4 tem por objetivo compreender um pouco mais como estão os vínculos externos das economias centro-oestinas com os seus principais parceiros internacionais naquilo que se refere aos produtos manufaturados, uma vez que $\mathrm{o}$ vetor externo, depois dos anos 1990, tornou-se uma fonte de estimulo para a difusão do progresso técnico nas estruturas produtivas locais.

\section{A EVOLUÇÃO DAS EXPORTAÇÕES DE PRODUTOS MANUFATURADOS DA REGIÃOO CENTRO-OESTE}

Um dos pontos centrais das evidências teóricas destacadas pela CEPAL refere-se ao papel que a inserção externa teve como elemento indutor do progresso técnico nas estruturas produtivas das economias periféricas. Este ponto foi salientado, no quadro de evolução das ideias cepalinas, por Prebisch $(1951$, p. 8) quando destacou que “(...) os novos métodos de produção atingem, em primeiro lugar, àquelas atividades que estáo ligadas, por um meio ou outro, à exportação de gêneros alimentícios e matérias primas".

Mesmo que a assertiva de Prebisch (1951) esteja ancorada em um momento especifico do processo de industrialização das economias latino-americanas (industrializaçáo leve), é importante destacar que, para o caso da regiāo Centro-Oeste, dado a especificidade do seu estilo de desenvolvimento iniciado na década de 1990, essa asseveraçáo ainda mantém certa aderência às evidências empíricas deste espaço regional. Isto porque a força externa tornou-se preponderante neste espaço regional vis-à-vis a força interna naquilo que se refere aos determinantes do estilo de desenvolvimento centro-oestino. 
Desde os anos 1990, o estilo de desenvolvimento do Centro-Oeste - moldado entre as décadas de 1930 e 1980 para caracterizar-se como atividade complementar à economia paulista - apresentou uma fissura em decorrência da perda da capacidade do Estado em promover um conjunto de projetos de desenvolvimento regional em consequência da crise fiscal e financeira que o Brasil vivenciou nos anos de 1980. Deste modo, houve uma rotação no eixo de força do estilo de desenvolvimento das economias centro-oestinas, com as forças externas passando a ter maior ascendência vis-à-vis as forças internas, uma vez que estas economias locais se tornaram complementares e integradas aos mercados internacionais.

Assim, a lógica de acumulação destas economias se integrou, de forma singular, em um contexto que Samuel (2013, p. 14) destacou como tendo seu invólucro expresso na

(...) fronteira agrícola moderna, o poder das grandes empresas (tradings, agroindústrias, sementes, fertilizantes e agrotóxicos) se expressa através da regulação das inovaçôes tecnológicas, do financiamento de custeio, do fortalecimento de insumos, do comércio e da logística de circulaçáo dos grãos.

Em outras palavras, a forma de constituição do vetor tecnológico fica cada vez mais dependente das empresas transnacionais para a aquisição e difusão de inovaçôes tecnológicas em seus sistemas produtivos agrícolas e industriais. Quer dizer, os países periféricos possuem uma forte dependência da ciência e da tecnologia elaborada autonomamente nos países centrais do capitalismo mundial.

Nesta perspectiva, o trabalho de Cavalcante (2011, p. 26), que versou sobre as desigualdades regionais em ciência, tecnologia e inovação (CT\&I) no Brasil, apontou para o fato que do total de empresas que implantaram inovaçôes tecnológicas no país, no interregno de 1998 a 2005, aquelas localizadas na região Centro-Oeste responderam por 4,39\% (1998-2000), 4,98\% (2000-2003) e 4,78\% (2003-2005). Ao passo que as empresas localizadas na regiáo Sudeste registraram valores bem superiores, ou seja, de $55,72 \%$ (1998-2000), 52,52\% (2000-2003) e 52,80\% (2003-2005). Isto posto, os dados indicam que as empresas localizadas na regiáo Centro-Oeste apresentam pouca capacidade endógena de geração de CT\&I. 
Assim, os impulsos do progresso técnico que são transmitidos pelo vetor externo para as economias periféricas são distribuídos de forma heterogênea entre os agentes econômicos, o que reforça, por conseguinte, o processo de heterogeneidade estrutural - um dos indicadores que apontam para a existência do subdesenvolvimento nestas economias.

Em vista disto, está seção tem por objetivo apresentar o cenário das exportaçóes da regiáo Centro-Oeste no período de 1990 a 2019, destacando em especial quais são os principais blocos econômicos que apresentaram parcerias comerciais com este espaço regional, bem como quais produtos sobressaíram em sua pauta exportadora. ${ }^{25}$

Como é destacado no gráfico 5 , os destinos das exportaçóes de produtos manufaturados da região Centro-Oeste, desde os anos de 1990, concentram-se, em especial, na União Europeia (em inglês, European Union - EU) e no Acordo de Livre Comércio da América do Norte (NAFTA). Em 1990, quase 73\% das exportaçóes de produtos manufaturados centro-oestinos tiveram como destino estes blocos, sendo que, quase $50 \%$ deste valor se direcionou para a EU. No entanto, é importante salientar que, no ano citado, os países africanos tiveram um papel importante no contexto das exportaçóes centro-oestinas, uma vez que demandaram pouco mais de $9 \%$ dos produtos manufaturados.

Em 2019, estes dois blocos juntos, EU e NAFTA, responderam por quase 44\% das exportaçôes de produtos manufaturados da regiấo Centro-Oeste. Entretanto, é importante ressaltar que a EU, desde o ano de 2016, vem perdendo participação relativa no total exportado de produtos manufaturados da região Centro-Oeste, ao passo que o NAFTA vem ganhando força como destino dos produtos manufaturados. Ou seja, a EU demandou quase $18 \%$ do total exportado de produtos manufaturados, ao mesmo tempo que, o NAFTA respondeu por $26 \%$.

25. Um aprofundamento sobre exportações e importações dos produtos do Centro-Oeste foi elaborada com maiores detalhes em Pires (2019). 
GRÁFICO 5

Blocos Econômicos de destino das exportações de produtos manufaturados - Centro-Oeste (1990-2019)

$(\mathrm{Em} \mathrm{R} \$)^{1}$

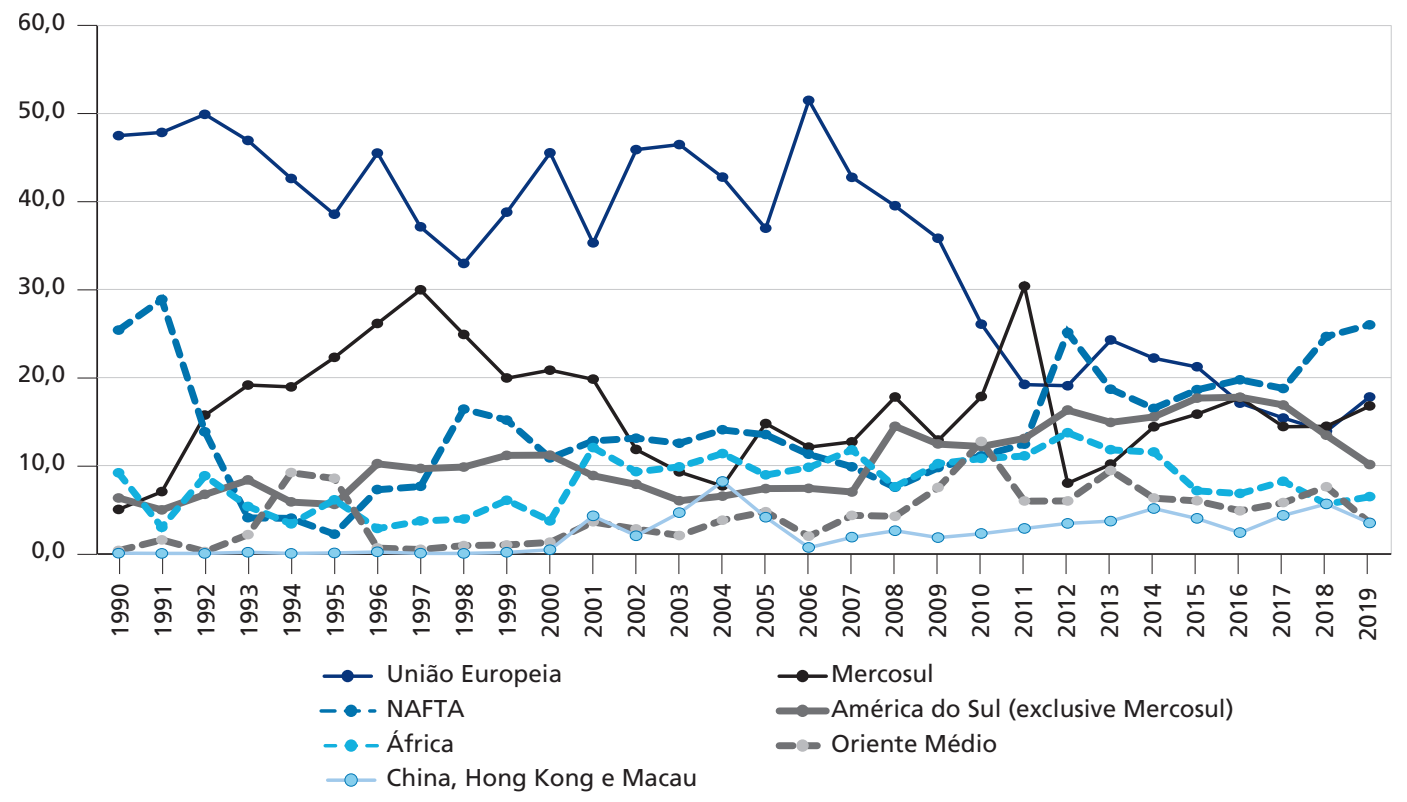

Fonte: Secretaria de Comercio Exterior do Ministério da Economia.

Elaboração do autor.

Nota: ' Valores constantes de 2019. Deflacionado pelo índice Consumer Price, dos Estados Unidos. Esse índice pode ser encontrado no banco de dados do Bank for International Settlements (BIS), cujo código da variável é A:US:628. Para maiores detalhes consulte <https://bit.ly/2SQAdPN>.

Um fato que merece destaque refere-se ao incremento dos países da América do Sul como destino das exportaçóes de produtos manufaturados da regiáo Centro-Oeste. Em 1990, os países sul-americanos concentravam pouco mais de 11\% das exportaçóes de produtos manufaturados da região Centro-Oeste, enquanto, em 2019, estes valores saltaram para quase $27 \%$.

Por fim, em termos de taxa de crescimento real das exportaçôes de produtos manufaturados da regiáo Centro-Oeste, os destinos que apresentaram maiores crescimentos, entre 1990 a 2019, foram: China, Hong-Kong e Macau, com quase 30\% a.a.; seguidos pelo bloco da Associação de Nações do Sudeste Asiático (ASEAN), com pouco mais de $25 \%$ a.a.; Oriente Médio, com quase $18 \%$ a.a.; e, por fim, Oceania, com $17,5 \%$ a.a. 
Em vista disto, constata-se que há um movimento crescente, por parte dos países asiáticos, em demandarem produtos manufaturados da regiáo Centro-Oeste. Quer dizer, há indícios que, mantendo a tendência atual, no porvir, estes blocos econômicos podem vir a ser grandes parceiros comerciais das UFs centro-oestinas, da mesma maneira que fizeram com os produtores de commodities agrícolas e minerais.

\section{GRÁFICO 6}

Razão entre os valores dos principais componentes das exportações em relação ao valor total exportado - Centro-Oeste (1990-2019)

(Em \%)

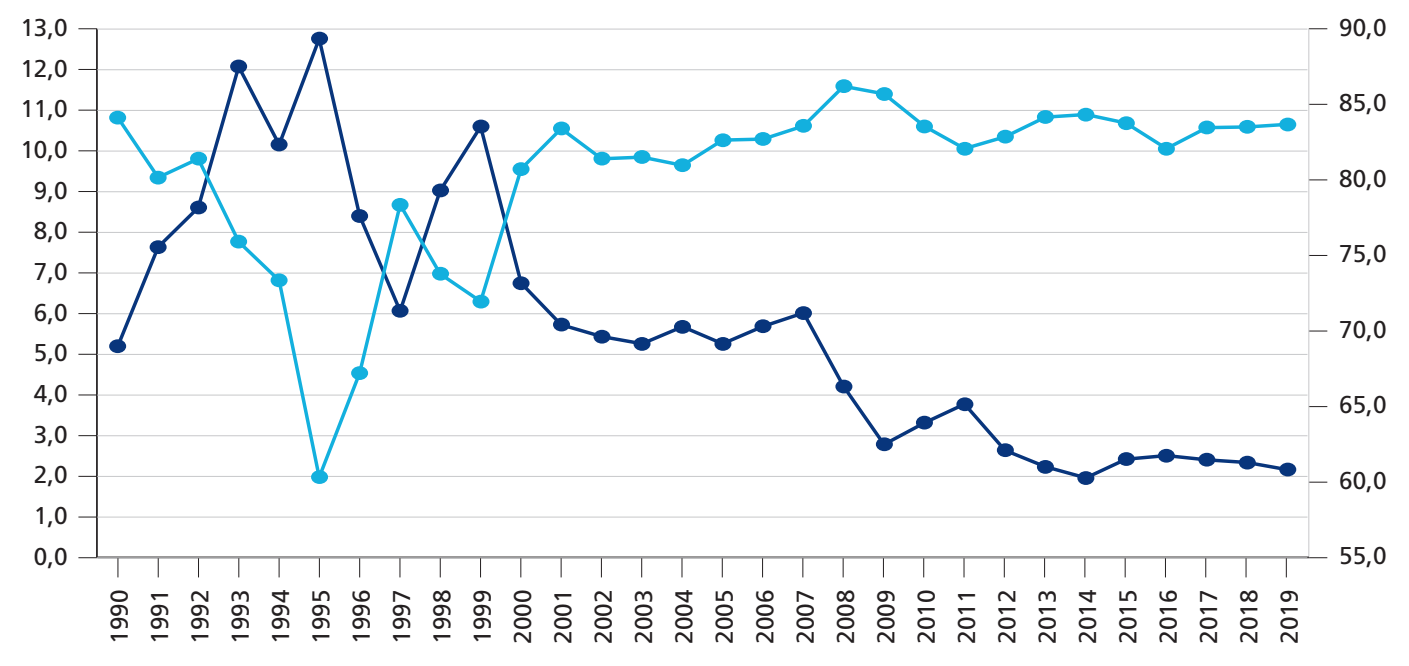

$\longrightarrow$ Razão produtos manufaturados $\longrightarrow$ Razão produtos básicos

Fonte: Secretaria de Comercio Exterior do Ministério da Economia.

Elaboração do autor.

Como apontado no gráfico 6 , as exportaçóes de produtos manufaturados da regiáo Centro-Oeste foram predominantes entre 1990 a 1998; porém, com uma inversão cíclica depois da crise cambial de 1999, quando as exportaçôes de produtos básicos se tornaram hegemônicos na balança comercial centro-oestina. Isto é, desde os anos 2000, a pauta exportadora da região Centro-Oeste vem se especializando em produtos que apresentam vantagens comparativas no mercado internacional, por exemplo, commodities agrícolas e minerais - ou seja, produtos com baixo valor agregado. ${ }^{26}$ 
Em síntese, os destinos das exportações dos produtos manufaturados da região Centro-Oeste, no período de 1990 a 2019, concentraram-se, em especial, nos principais países centrais do capitalismo mundial, particularmente em um contexto que as exportaçóes de produtos manufaturados vêm, dia após dia, perdendo espaço para os produtos básicos na balança comercial da região Centro-Oeste.

Isso significa que as unidades de produção industrial no Centro-Oeste - para se manterem competitivas nos países centrais - tiveram que incorporar o conhecimento cientifico e tecnológico, desenvolvidos em grande parte nas economias centrais, em seus processos de produção; caso contrário, perderiam ainda mais espaços para os concorrentes nos mercados internacionais. ${ }^{27}$

\section{UMA COMPARAÇÃO ENTRE A PT INDUSTRIAL SETORIAL POR FATORES DE COMPETITIVIDADE DAS UFS QUE CONSTITUEM A REGIÃO CENTRO-OESTE VIS-À-VIS AO ESTADO DE SÃO PAULO}

O processo de modernização das estruturas econômicas da região Centro-Oeste iniciou-se nos anos 1930, por meio da integração deste espaço regional com o principal polo dinâmico nacional: o estado de Sáo Paulo. Pelos trilhos da Companhia Mogiana de Estradas de Ferro, os ventos da modernização avançaram pelo interior de São Paulo e penetraram a regiāo Sul do estado de Goiás, por meio da Estrada de Ferro Goiás, que conectou o Triangulo Mineiro com Ipameri, Roncador, Pires do Rio, Engenheiro Leopoldo de Bulhões, Anápolis e Goiânia.

As bases da "Macha para o Oeste", de Getúlio Vargas, estavam estabelecidas não apenas pelos eixos de integração proporcionados pela conexão ferroviária, mas também pela construção de Goiânia e a constituiçãa das Colônias Agrícolas Nacionais de Goiás (1941-1946) e de Dourados (1943-1955). Estas tiveram um papel importante na equalização dos conflitos agrários existentes - em especial no Pontal do Paranapanema, localizado no estado de São Paulo.

27. É interessante verificar a reportagem de Almeida (2020). 
Estes fatos, acrescidos ao deslocamento do eixo de integração nacional para o interior do Brasil, por meio da construção de Brasília (1960), favoreceram a integração da região Centro-Oeste com o restante dos mercados nacionais. Assim, as bases para as transformaçóes nas estruturas produtivas centro-oestinas estavam postas e se objetivaram a partir dos anos 1960, com os projetos de modernização da estrutura agrícola da região que vieram no contexto do II PND. ${ }^{28}$

Deste modo, o crescimento da produção agrícola da região se expande, sobretudo, impulsionado pelas inovaçóes tecnológicas desenvolvidas pela Revoluçáo Verde que incorporou, nas unidades de produção agrícola da região, as inovações biológicas, físico-químicas e mecânicas, as quais incrementaram a produção, em especial, de culturas voltadas para o mercado externo e com fácil integração às cadeias produtivas agroindústrias - como foram os casos de soja e milho. ${ }^{29}$

É em meio ao vetor de expansão agrícola que as tradings companies chegaram na região, a partir dos anos 1980, com o objetivo de absorverem e incrementarem a produção destas culturas de base exportadora. ${ }^{30}$ Com o incremento da produção agrícola e com os planos de incentivos e benefícios fiscais promovidos pelos governos das UFs do Centro-Oeste, os financiamentos públicos feitos pelo Fundo Constitucional do Centro-Oeste (FCO) ${ }^{31}$ e pelo Banco Nacional de Desenvolvimento Econômico e Social (BNDES), juntamente com os financiamentos privados, alavancaram os investimentos em setores industriais na regiāo. ${ }^{32}$

28. Para maiores detalhes, ver Pires (2008).

29. Para Castro e Fonseca (1995, p. 2): "(...) verifica-se, na segunda metade dos anos 80, um deslocamento de grandes conglomerados industriais que para lá transferem fábricas de beneficiamento de grãos e atividades integradas de criação e abate de pequenos animais. A região Centro-Oeste caracterizou-se, assim, nos anos 80, por ser um polo de atração de capitais do Centro-Sul, especialmente, das empresas líderes do complexo agroindustrial, que tenderam a ocupar posições estratégicas". 30. No ano de 2019, a lista cadastral de empresas exportadoras do Ministério da Economia apontava para a existência de 27.545 unidades espalhadas pelo território brasileiro. Deste total, quase 44\% das empresas estavam localizadas no estado de São Paulo -centro dinâmico do capitalismo nacional. Em seguida, vieram Rio Grande do Sul, com pouco mais de 11\%; Paraná, com 9, 1\%; e Santa Catarina, com 8,4\%. Juntos, esses quatro estados concentraram quase $72 \%$ do total das empresas exportadoras. No caso da região Centro-Oeste, observa-se que o estado do Mato Grosso concentrou 1,6\% do total das empresas exportadoras nacionais, porém, seguido pelos estados de Goiás com 1,4\%, Mato Grosso do Sul com 0,8\% e, por fim, o Distrito Federal com 0,3\%. Assim, a região Centro-Oeste centralizou pouco mais que $4 \%$ das empresas exportadoras nacionais.

31. Para maiores detalhes, ver Pires (2017).

32. Para detalhes, ver Castro e Fonseca (1995), Estevam (1998) e Pires (2008; 2016; 2019). 
Com a mudança no estilo de desenvolvimento do Centro-Oeste a partir dos anos 1990, o processo de integração da região aos mercados internacionais foi estimulado por meio dos Enid, que se estabeleceram no contexto da liberalização e desregulamentação da economia nacional. Os estímulos externos e internos, proporcionados pelo Estado e pelo capital privado nacional e internacional, incrementaram o produto agrícola e industrial da regiáo, o que favorece, assim, as modificaçóes produtivas (agrícolas e industriais) neste espaço regional.

Como asseverado por Samuel (2018, p. 13),

O início do século XXI marcou a chegada de uma nova safra de capitalistas na agricultura mundial. Trata-se da presença do capital financeiro, representado por diversos tipos de fundos (pensão, soberanos, hedge, endowments, private equity), corporações (bancos, seguradoras e empresas) e indivíduos de alta renda, sobretudo, nos países de maior produção agrícola e com dinâmicas de fronteira como o Brasil.

Em vista disto, a agropecuária acelerou o seu processo de modernização e seus custos de produção tornaram mais competitivos, em decorrência da grande produção de grãos, incentivando, portanto, a entrada de grandes empresas dos setores agroindustriais neste espaço regional que tiveram por objetivo aproveitar o potencial de matérias-primas ofertadas pelos produtores rurais. ${ }^{33} \mathrm{Em}$ vista disto, há um avanço nos setores agroindustriais, sobretudo aqueles relacionados com os complexos: soja, milho, carnes, lácteo e sucroalcooleiro; e, recentemente, farmoquímicos e farmacêuticos, máquinas, equipamentos e veículos automotores.

As transformações na estrutura industrial da região Centro-Oeste foram destacadas em Pires (2019, p. 19) que, ao analisar o período de 2007 a 2016, apurou que “(...) a razão do VBPI do Centro-Oeste vis-à-vis regiōes Norte e Nordeste indica que o crescimento industrial dos estados do Centro-Oeste, no período destacado, apresentou um incremento bem acima do encontrado para as regiôes Norte e Nordeste".

33. Essa integração da região Centro-Oeste com os mercados globalizados ampliou a importância que o capital privado tinha na determinação da alocação dos recursos humanos e materiais, como também nos mecanismos de financiamento aos investimentos de modernização das unidades de produção agropecuárias da região. Segundo Samuel $(2013$, p. 14): "(...) além do uso dos novos sistemas técnicos informacionais, a agricultura cientifica globalizada também se caracteriza por uma forma de regulação política. Na fronteira agrícola moderna, o poder das grandes empresas (tradings, agroindústrias, sementes, fertilizantes e agrotóxicos) se expressa através da regulação das inovações tecnológicas, do financiamento de custeio, do fortalecimento de insumos, do comércio e da logística de circulação dos grãos". 
No entanto, os setores industriais que mais se despontaram no Centro-Oeste durante o período 2007-2016 foram aqueles relacionados com fabricação de produtos alimentares, setores de fabricação de coque, de produtos derivados do petróleo e de biocombustíveis, produtos químicos, fabricação de celulose, papel e produtos de papel, bebidas e, por fim, o setor de fabricação de produtos de minerais não metálicos. Juntos, esses setores responderam por $83,0 \%$ do valor bruto total da produção industrial da região Centro-Oeste no ano de 2016.

Assim, as últimas quatro décadas marcaram profundamente a estrutura industrial centro-oestina, sobretudo, por impulsionarem o seu crescimento industrial, todavia alicerçados nos setores que apresentaram fortes ligações com os elos das cadeias produtivas nacionais e internacionais.

Mesmo que o estado de São Paulo ainda continue como o eixo do capital industrial nacional e os investimentos industriais estejam espraiados pelo polígono destacado por Diniz (1993) e Monteiro Neto, Silva e Severian (2020), ainda assim é importante ressaltar a relevância que os mesmos tiveram no contexto da região Centro-Oeste, a qual é objeto de estimulo da II PNDR.

Por exemplo, em 1996, o VTI na região Norte era quase 4\% do total nacional, ao passo que na região Nordeste era 8,3\%, e no Centro-Oeste era 2,4\%. Em 2016, estas participaçóes eram as seguintes: a região Norte com 6,2\%, o Nordeste com $10,6 \%$ e a região Centro-Oeste com $6,0 \% .^{34}$

É neste contexto, que os setores industriais da região Centro-Oeste vão se transformando e impulsionando o crescimento industrial da região. Em 1996, a participação da região no total nacional do VTI era 2,4\%; ao passo que, em 2006, era 3,7\%; e, em 2016,

34. Observa-se que, no âmbito dos estados que formam a região Centro-Oeste, o VTI do Distrito Federal apresentou uma taxa de crescimento real de pouco mais de 4\% a.a., entre 2007 e 2016, ao passo que, o estado de Goiás teve uma expansão superior a 6,5\% a.a., o Mato Grosso teve 6,5\% a.a. e, por fim, o Mato Grosso do Sul teve 8,0\% a.a. Estas taxas de crescimento ficaram bem acima da média nacional, que foi de 2,0\% a.a. No caso do PO na atividade industrial, verifica-se, para o mesmo período, que a taxa de crescimento real para o Distrito Federal foi de quase 4,0\% a.a., enquanto, para 0 estado de Goiás foi de quase 6,0\% a.a., para o Mato Grosso um pouco mais que 5,0\% a.a. e, finalmente, o Mato Grosso do Sul com 7,0\% a.a. Estas taxas de crescimento da população ocupada no setor industrial foram bem superiores aquela encontrada para a média brasileira que foi de 1,9\% a.a. 
correspondia 6,0\%. Quer dizer, sua participação no total do VTI industrial mais que duplicou. Entre as UFs que mais se destacaram no regiáo Centro-Oeste, encontram-se Goiás com 2,9\% (2016), Mato Grosso e Mato Grosso do Sul, ambos com 1,4\% (2016) e, por fim, o Distrito Federal com 0,3\% (2016).

Em relação à difusão do progresso técnico, que em grande parte se objetiva por apropriação de pacotes tecnológicos difundidos nos mercados internacionais, na estrutura industrial centro-oestina, observa-se que a expansão da produtividade média do trabalho industrial dos estados do Centro-Oeste vis-à-vis ao estado de São Paulo (gráfico 6) foi mais acentuada em Mato Grosso do Sul e Mato Grosso, essencialmente depois da crise financeira de 2008, quando se despontaram no contexto centro-oestino.

Como o estado de Sáo Paulo concentra parte importante dos setores industriais nacionais, então, os efeitos da crise econômica foram maiores neste espaço regional em face às UFs do Centro-Oeste, que apresentam fortes vínculos com o vetor externo da economia nacional.

GRÁFICO 7

Razão entre a produtividade média industrial do estado de São Paulo vis-à-vis às UFs da região Centro-Oeste (1996-2016)

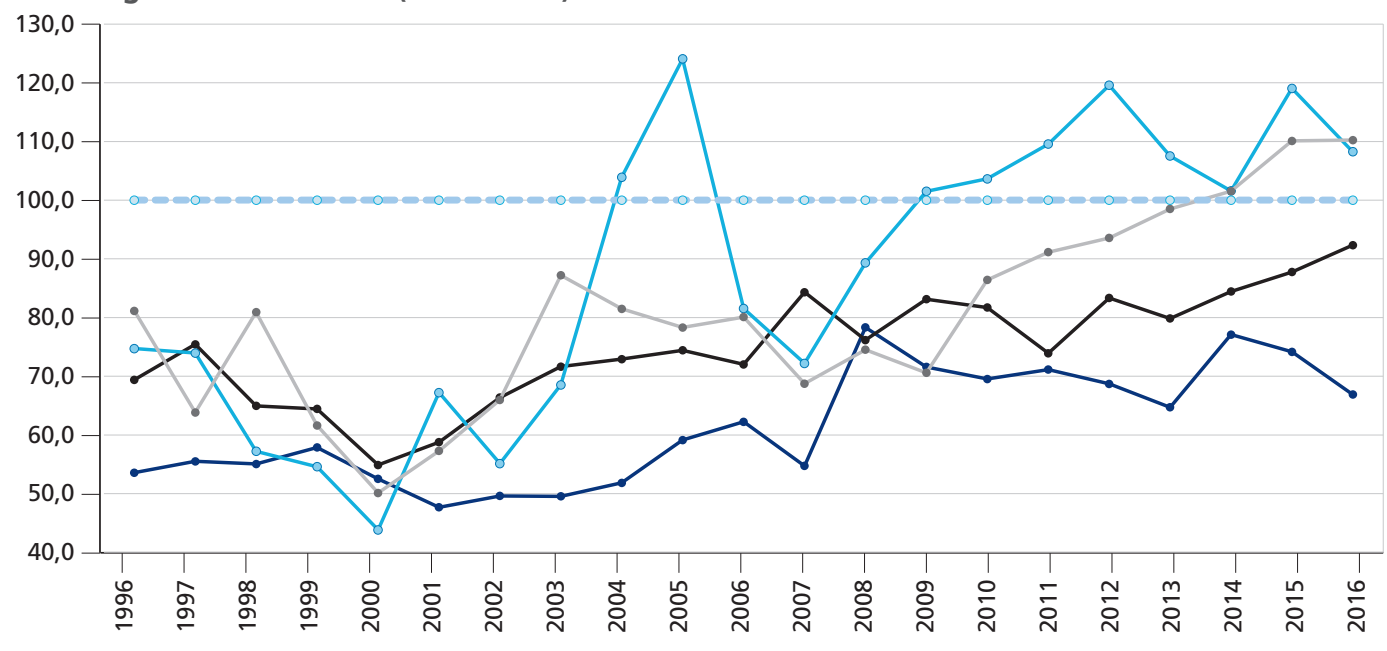

$\rightarrow$ Distrito federal $\rightarrow$ Goiás $\rightarrow$ Mato grosso $\rightarrow$ Mato grosso do sul $\rightarrow$ São paulo 
Assim, o fato que merece destaque refere-se à redução do hiato existente entre a produtividade média do trabalho dos setores industrias paulistas vis-à-vis aos estados do Mato Grosso, do Mato Grosso do Sul e, em menor intensidade, de Goiás. Por exemplo: a taxa de crescimento real da produtividade média do trabalho dos setores industriais do estado do Mato Grosso cresceu 1,3\% a.a. no período analisado. Por sua vez, no Mato Grosso do Sul, o crescimento foi de quase 1\% a.a. Em Goiás, o crescimento foi de $0,8 \%$ a.a., no Distrito Federal foi 0,5\% a.a. Por fim, o estado de São Paulo teve um crescimento de $0,6 \%$ a.a.

TABELA 2

Razão entre a produtividade média do trabalho setorial industrial, por fatores de competividade do estado de São Paulo vis-à-vis às UFs da região Centro-Oeste

\begin{tabular}{|c|c|c|c|c|c|}
\hline $\begin{array}{l}\text { Produtividade média do trabalho por setores relacio- } \\
\text { nados a fatores de competividade }\end{array}$ & 1996 & 2001 & 2006 & 2011 & 2016 \\
\hline Distrito Federal & 0,54 & 0,48 & 0,62 & 0,71 & 0,67 \\
\hline Baseado em ciência & 0,52 & 0,03 & 0,03 & 0,51 & 0,80 \\
\hline Baseado em recursos naturais & 0,37 & 0,34 & 0,49 & 0,63 & 0,59 \\
\hline Diferenciado & 1,25 & 0,77 & 0,90 & 0,40 & 0,42 \\
\hline Intensivo em escala & 0,59 & 0,47 & 0,46 & 0,69 & 0,54 \\
\hline Intensivo em trabalho & 0,38 & 0,44 & 0,89 & 0,57 & 0,80 \\
\hline Goiás & 0,69 & 0,59 & 0,72 & 0,74 & 0,92 \\
\hline Baseado em ciência & 0,49 & 0,19 & 0,23 & 0,30 & 0,16 \\
\hline Baseado em recursos naturais & 0,67 & 0,52 & 0,66 & 0,64 & 0,84 \\
\hline Diferenciado & 0,32 & 0,54 & 0,38 & 0,84 & 0,92 \\
\hline Intensivo em escala & 0,68 & 0,54 & 0,71 & 0,68 & 0,89 \\
\hline Intensivo em trabalho & 0,35 & 0,39 & 0,48 & 0,70 & 0,74 \\
\hline Mato Grosso & 0,75 & 0,67 & 0,82 & 1,10 & 1,08 \\
\hline Baseado em ciência & 0,37 & 0,00 & 0,24 & 0,37 & 0,22 \\
\hline Baseado em recursos naturais & 0,53 & 0,46 & 0,58 & 0,88 & 0,89 \\
\hline Diferenciado & 0,18 & 0,19 & 0,60 & 0,31 & 0,42 \\
\hline Intensivo em escala & 0,46 & 0,42 & 0,55 & 0,96 & 1,07 \\
\hline Intensivo em trabalho & 0,52 & 0,99 & 0,73 & 0,95 & 1,16 \\
\hline Mato Grosso do Sul & 0,81 & 0,57 & 0,80 & 0,91 & 1,10 \\
\hline Baseado em ciência & 0,67 & 0,25 & 0,25 & 0,27 & 0,12 \\
\hline Baseado em recursos naturais & 0,62 & 0,40 & 0,62 & 0,74 & 0,95 \\
\hline Diferenciado & 0,35 & 0,34 & 0,75 & 0,90 & 1,03 \\
\hline Intensivo em escala & 0,24 & 0,25 & 0,48 & 0,63 & 0,68 \\
\hline Intensivo em trabalho & 0,62 & 0,96 & 0,87 & 1,28 & 1,37 \\
\hline
\end{tabular}

Fonte: Pesquisa Industrial Anual - Empresa do IBGE.

Elaboração do autor.

Nota: Tipologias retiradas em Monteiro Neto e Silva (2018), a partir de sugestões de Bolbély (2004). 
Os dados da tabela 2 salientam que alguns setores que constituem o tecido industrial centro-oestino apresentaram uma redução no hiato da produtividade média do trabalho industrial vis-à-vis aos seus similares no estado de São Paulo. Em resumo, os setores industriais que mais se evidenciaram nas UFs que formam a região Centro-Oeste foram classificadas conforme a taxonomia da indústria destacada em Monteiro Neto e Silva (2018).

QUADRO 1

Setores industriais por fatores de competividade que apresentaram redução do hiato de produtividade média do trabalho vis-à-vis ao estado de São Paulo - Centro-Oeste

\begin{tabular}{|l|l|l|l|}
\hline Distrito Federal & Goiás & Mato Grosso & Mato Grosso do Sul \\
\hline Baseado em ciências & Baseado em recursos naturais & Baseado em recursos naturais & Baseado em recursos naturais \\
\hline Baseado em recursos naturais & Diferenciado & Diferenciado & Diferenciado \\
\hline Intensivo em trabalho & Intensivo em escala & Intensivo em escala & Intensivo em escala \\
\hline & Intensivo em trabalho & Intensivo em trabalho & Intensivo em trabalho \\
\hline
\end{tabular}

Elaboração do autor.

Na maior parte dos casos, excluso o Distrito Federal, o setor baseado em ciências - relacionado com maquinários para escritório, computação e área farmacêutica e que apresenta uma aplicação imediata de pesquisa cientifica - não apresentou um papel significativo entre os setores indústrias que exibiram uma redução no diferencial de produtividade média do trabalho da regiáo Centro-Oeste quando comparada com o estado de São Paulo.

Os setores que mais sobressaíram foram aqueles vinculados ao acesso a recursos naturais, quer dizer, associados com os setores de alimentos, madeira, petróleo, biocombustíveis e mineral (ferro, manganês e níquel). Esses setores apresentaram uma produtividade média do trabalho significativa no contexto inter-regional, porém, concentrada mormente na produção de derivados de soja, milho, cana-de-açúcar e carnes (bovino, suíno e aves).

Ademais, o baixo custo da máo de obra centro-oestina foi um fator importante para a atração de atividades empresariais para o setor intensivo em trabalho - por exemplo, os setores têxteis, de couro, de sapatos e de móveis. Estes setores tiveram um papel singular, pois reduziram o diferencial da produtividade média do trabalho industrial na região Centro-Oeste vis-à-vis ao estado de São Paulo. 
Além disso, o setor de diferenciados que tem como finalidade elaborar produtos para atenderem características diversificadas da demanda local (como produtos elétricos e eletrônicos) teve um papel importante nos estados de Goiás e Mato Grosso do Sul, pois sua produtividade média apresentou uma redução no hiato existente vis-à-vis aos setores similares de São Paulo. No caso do Mato Grosso, constata-se que o diferencial da PT industrial vis-à-vis ao estado de São Paulo não apresentou a mesma intensidade que aquela verificada para Goiás e Mato Grosso do Sul.

Por fim, as empresas que apresentaram cadeias produtivas mais extensas, como os setores de veículos automotores e de aço, por exemplo, tiveram um peso significativo na redução do hiato da produtividade média dos setores industriais centro-oestinos ao confrontá-lo com os seus análogos no estado de São Paulo.

GRÁFICO 8

CV da produtividade média entre os setores industriais de São Paulo vis-à-vis às UFs da região Centro-Oeste

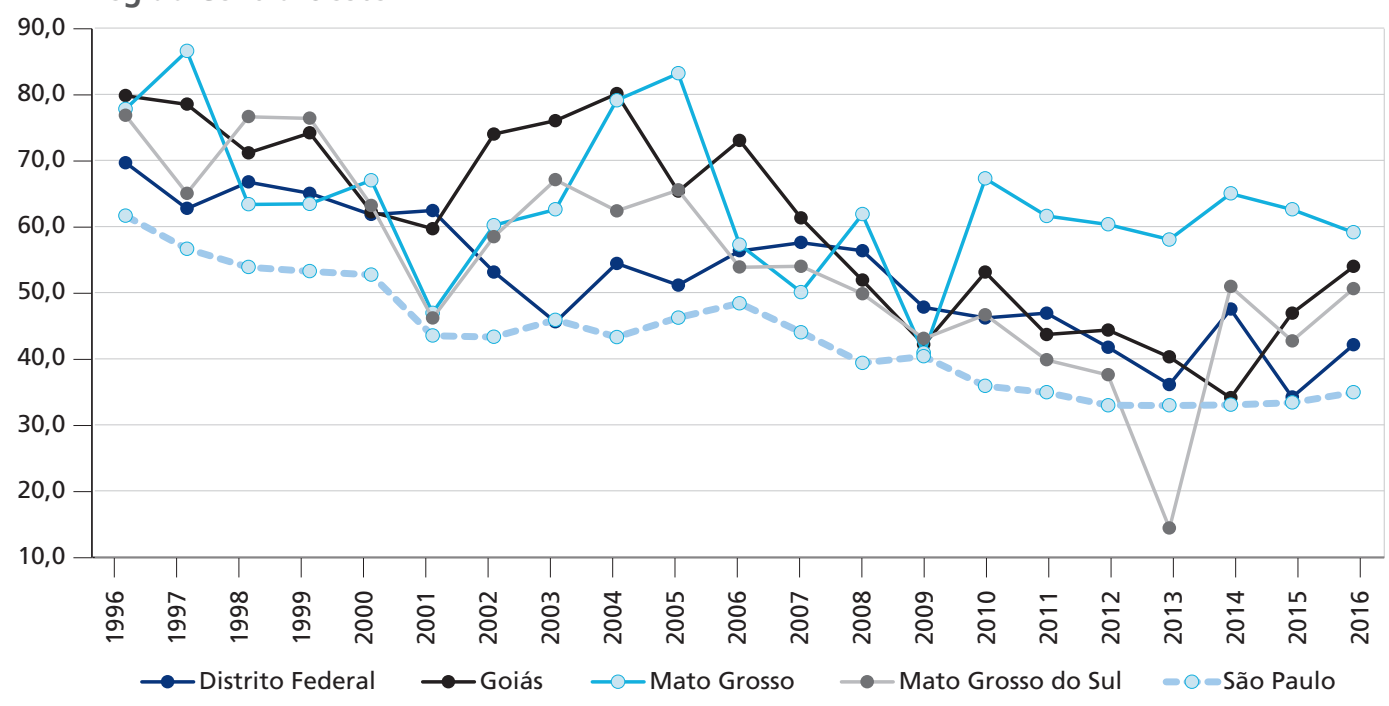

Fonte: Pesquisa Industrial Anual - Empresa do IBGE. Elaboração do autor

Em resumo, é importante registrar que, no período de 1996 a 2016, nota-se (gráfico 8) uma redução paulatina no grau de heterogeneidade da produtividade média do trabalho entre os setores industriais que constituem as UFs do Centro-Oeste e o estado São Paulo. Em 1996, o estado de Goiás apresentou o maior grau de heterogeneidade entre os setores dos estados analisados, porém seguido pelo Mato Grosso, Mato Grosso 
do Sul, Distrito Federal e, finalmente, São Paulo que exibiu a maior homogeneidade entre os setores industriais. Em 2016, quem obteve maior grau de heterogeneidade em termos de produtividade média do trabalho, entre os setores industriais, foi o estado do Mato Grosso, seguido por Goiás, Mato Grosso do Sul, Distrito Federal e, por último, São Paulo.

Suscintamente, identifica-se que a redução no grau de heterogeneidade entre a produtividade média do trabalho nos setores industriais que formam a região Centro-Oeste, entre 1996 a 2016, vis-à-vis ao estado de Sáo Paulo, é um sinal claro que os efeitos proporcionados pelo incremento do progresso técnico, na matriz industrial da região, está proporcionando a modernização dos setores industriais de suas UFs, visto que estáo constantemente incorporando novas tecnologias aplicadas em suas estruturas industriais para fazerem face à concorrência acirrada que há nos mercados globalizados.

No entanto, esse movimento não teve forças suficientes para superar o subdesenvolvimento que é característico destas economias, uma vez que há a existência, no mesmo espaço e tempo, de estruturas industriais modernas e atrasadas. Quer dizer, não houve uma certa homogeneização da estrutura industrial, dado que as forças externas não tiveram potência suficiente para difundir o progresso técnico de forma equânime entre os setores econômicos do Centro-Oeste.

\section{OBSERVAÇÕES FINAIS}

Como foi destacado, este texto tem como objetivo verificar se há alguma redução no hiato existente entre a produtividade média do trabalho dos setores industriais por fatores de competitividade nas UFs que formam a regiāo Centro-Oeste vis-à-vis ao estado de São Paulo, no período de 1996 a 2016. Neste sentido, observa-se que a estrutura industrial brasileira é marcada por uma forte heterogeneidade estrutural, relacionada com sua formaçáo econômica, ou seja, a forma que se objetivou o estilo de desenvolvimento econômico nacional.

Assim, o progresso técnico, no período do Modelo de Substituição de Importaçôes (1930-1980), penetrou as estruturas industriais nacionais por meio da incorporação expressiva de inovaçôes tecnológicas provenientes dos países centrais. Estas inovaçóes 
estavam moldadas para um padrão de acumulação de capital díspar daquele encontrado em uma economia periférica. Esse processo criou um descompasso inter-regional na difusão do progresso técnico, uma vez que a estrutura produtiva brasileira, que é marcada pelo subdesenvolvimento, se desenvolveu em um contexto no qual o hiato estrutural insulou o lado moderno, que consegue absorver inovações tecnológicas; entretanto, o lado arcaico e tradicional manteve-se refratário ao processo de modernização.

Desta forma, a economia brasileira foi avançando em seu processo de industrialização, porém com o lado moderno e atrasado convivendo, sincronicamente, um ao lado do outro no mesmo espaço e tempo. Mesmo que o processo de industrialização tenha avançado em seus estádios superiores, ainda assim a superação do subdesenvolvimento não foi equacionada. $\mathrm{O}$ que se objetivou, em nível regional, foi o transbordamento do desenvolvimento industrial pelo tecido regional que seguiu o sulco do polígamo destacado por Diniz (1993) e Monteiro Neto, Silva e Severian (2020).

Historicamente, a tessitura do tecido industrial entre as UFs foi marcada por se assentar em uma heterogeneidade industrial que ainda tem caráter marcante em termos estruturais. Este fato nos permite destacar o papel hegemônico da estrutura industrial de São Paulo vis-à-vis às demais regióes brasileiras, as quais são economias complementares à paulista.

No caso especifico da região Centro-Oeste, em 1996, o Distrito Federal representava $0,3 \%$ da estrutura industrial paulista, ao passo que o estado de Goiás respondia por 2,4\%, Mato Grosso por 1,2\% e Mato Grosso do Sul 0,9\%. Em 2016, estes valores eram respectivamente $0,8 \%$ para o Distrito Federal, 8,6\% para o estado de Goiás, 4,2\% para os estados de Mato Grosso e Mato Grosso do Sul.

Quando se adota a produtividade média do trabalho como proxy para o progresso técnico, observa-se o seguinte retrato: entre as 27 UFs, nos anos de 1996 a 2016, constata-se que a participação dos estados que apresentaram uma produtividade industrial acima daquela aferida para a média nacional foram 41\% (1996), 33\% (2001), 37\% (2006), $33 \%$ (2011) e 41\% (2016). Isto quer dizer que do total das UFs, pouco menos de onze conseguiram apresentar uma produtividade industrial acima daquela aferida para a média da economia nacional. Esses dados mostram que o grau de heterogeneidade do tecido industrial regional brasileiro ainda é muito acentuado, em particular, nas regióes Norte 
e Nordeste. Essa acentuação ocorre porque as dispersōes da PT industrial destas regiōes foram mais volumosas em relação à média nacional, assim como aquelas aferidas para as regióes do Sudeste, Centro-Oeste e Sul.

Isto significa que o espraiamento do progresso técnico entre as unidades produtivas industriais se cristalizou de forma assimétrica, dado que houve empresas que incorporaram com maior intensidade inovaçóes tecnológicas em seus processos de produção, enquanto outras se mantiveram agarradas aos grilhóes da economia de subsistência e atrasadas.

No entanto, é importante ressaltar que estados como Amazonas, Bahia, Espirito Santo, Mato Grosso, Mato Grosso do Sul, Pará e Rio de Janeiro apresentaram uma produtividade industrial média superior ao estado de Sáo Paulo, visto que suas estruturas industriais estão fortemente enraizadas em setores intensivos em recursos naturais, como também em regiôes que apresentam fortes incentivos e benefícios fiscais - como os encontrados na ZFM-AM.

No caso especifico da região Centro-Oeste, constata-se que a rotação no eixo de forças que impulsionava as transformaçôes em suas estruturas produtivas determinou uma modificaçáo em seu estilo de desenvolvimento no período sequente aos anos de 1990. Antes de 1990, os fatores internos tiveram um papel fundamental para consolidar e integrar este espaço regional como uma economia complementar à paulista.

Com o processo de desregulamentação e abertura da economia nacional iniciado nos anos de 1990, a economia centro-oestina se conectou aos mercados internacionais por intermédio dos Enid, que tiveram um papel medular na promoção de um portfólios de investimentos públicos e privados que causassem na região modificaçóes na infraestrutura de transporte, logística e armazenamento de grãos, bem como para a redução da dependência do modo de transporte rodoviário vis-à-vis aos transportes ferroviário, hidroviário e composiçôes.

Assim, o estilo de desenvolvimento do Centro-Oeste se estruturou no sentido que as forças externas impulsionassem com maior intensidade, quando cotejado com as forças internas, as transformaçôes em suas estruturas produtivas de forma que suas UFs atendessem, majoritariamente, as demandas provenientes dos mercados internacionais. Não é por acaso que a soja foi introduzida no cerrado, desde meados dos anos 1960 , para impulsionar as transformaçôes na estrutura agrícola da região, bem como conectar a regiáo aos centros de consumo internacional. 
Deste modo, a agricultura intensificou seu processo de modernização, em especial, por meio da adoção de tecnologias provenientes da agricultura cientifica globalizada, o que amplificou o uso de tecnologias da fronteira do conhecimento mundial nas unidades produtivas locais e incrementando, por conseguinte, a produção agropecuária deste espaço regional.

Com matéria-prima em abundância, financiamento público e privado, proximidade do mercado interno pulsante do país e dos principais portos de exportação e incentivos e benefícios fiscais, a regiáo Centro-Oeste iniciou o seu processo de crescimento industrial, em especial nos setores relacionados com fabricação de produtos alimentares; nos setores de fabricação de coque, de produtos derivados do petróleo e de biocombustíveis, produtos químicos, fabricação de celulose, papel e produtos de papel, bebidas; e, por fim, no setor de fabricação de produtos de minerais não metálicos. Estes setores em conjunto foram responsáveis por 83\% do valor bruto da produção do Centro-Oeste no ano de 2016.

Isto teve um impacto significado na estrutura industrial regional, porque a região Centro-Oeste apresentou um crescimento bem acima das regióes Norte e Nordeste naquilo que se refere ao valor bruto da produção industrial entre 2007 e 2016 . Assim, ao se comparar a PT industrial da região Centro-Oeste vis-à-vis ao estado de São Paulo, constata-se que o hiato existente entre elas, no período de 1996 a 2016, vem, progressivamente, se reduzindo. Ou seja, há uma convergência entre as produtividades do trabalho industrial no âmbito destes espaços regionais. Não obstante, este fato não significa que houve uma convergência entre a participação do produto industrial dos setores que formam a estrutura da indústria de transformação das UFs que constituem a região Centro-Oeste vis-à-vis ao estado de São Paulo.

No entanto, é importante ressaltar que, entre 1996 e 2016, a UF centro-oestino que apresentou a maior taxa de crescimento da PT industrial foi Mato Grosso, porém seguida por Mato Grosso do Sul, Goiás, Distrito Federal e, por fim, o estado São Paulo. Este fato indica que a difusão do progresso técnico entre as UFs supracitadas se objetivou, em grande parte, por meio da difusão de pacotes tecnológicos adquiridos no mercado internacional, o que culminou no impulsionamento de suas estruturas industriais ao apresentarem um maior grau de homogeneização - mesmo sabendo que isto não significa a superação das condiçóes subdesenvolvimento. Os dados expressam que o tecido industrial no espaço regional do Centro-Oeste ainda mantém um hiato entre aquelas 
unidades produtivas que avançaram em seu processo de modernização e aquelas que ainda persistiram em adotarem sistemas produtivos atrasados e tradicionais.

Por outro lado, os setores industriais por fatores de competividade da região Centro-Oeste que apresentaram maior convergência em termos de PT industrial vis-à-vis ao estado de Sáo Paulo foram os baseados em recursos naturais, diferenciado, intensivo em escala e intensivo em trabalho. Com exceção do Distrito Federal, nenhuma UF do Centro-Oeste apresentou uma redução na lacuna entre o diferencial de PT industrial vis-à-vis ao estado de Sáo Paulo naquilo que se refere ao setor baseado em ciências.

Deste modo, é importante sublinhar que o grau de heterogeneidade entre os setores industriais que constituem as UFs do Centro-Oeste e o estado Sáo Paulo apresentou, no interstício de 1996 a 2016, um declínio - visto que os seus valores se aproximaram mais da média de cada UF - sinalizando, por conseguinte, que a difusão do progresso técnico seguiu pelo caminho de uma maior homogeneização inter-regional. Porém, é importante acentuar que esse declínio não confirma, na região Centro-Oeste, a superaçáo da dualidade existente entre as empresas que modernizaram e aquelas que ainda se mantiveram agarradas aos grilhôes das técnicas arcaicas e tradicionais.

Por fim, é relevante evidenciar que o vetor externo teve um papel importante de estimulo ao incentivar os investimentos de modernizaçáo das empresas centro-oestinas, uma vez que os destinos das exportaçóes manufatureiras se concentraram, sobremaneira, na EU e no NAFTA. Por outro lado, constata-se uma crescente expansão das exportaçóes para a região da Ásia, tendo como destino: China, Hong-Kong e Macau; os países que compõem a Associação das Nações do Sudeste Asiático (ASEAN); e, por fim, alguns países do Oriente Médio e da África.

Por outro lado, desde a crise cambial de 1999, as exportaçóes de produtos manufaturados da região Centro-Oeste vêm perdendo importância na pauta exportadora da regiâo. Em contrapartida, há um crescimento significativo das exportações de produtos básicos. Quer dizer, pouco a pouco, a regiáo Centro-Oeste vem se especializando na produção de produtos com baixo valor agregado em detrimento daqueles com maior valor agregado. 
Todos esses fatores estão refletindo no estilo de desenvolvimento da região, visto que parte importante dos produtos centro-oestinos estão dependentes de estratégias tecnológicas realizadas por empresas transnacionais que encontram nos países centrais parte importante das inovaçóes tecnológicas que são implantadas nas unidades de produção agrícola e industrial instaladas no Centro-Oeste.

Isto reforça a dependência tecnologia deste espaço regional em relação ao padrão tecnológico estabelecido nos países centrais, uma vez que as UFs da regiáo Centro-Oeste possuem pouca capacidade de geração endógena de CT\&I. Este fato reforça a necessidade de formulação de estratégias estaduais em CT\&I para reduzirem a dependência das UFs, no que concerne às inovaçôes tecnológicas que são produzidas nos países centrais.

\section{REFERÊNCIAS}

ALMEIDA, K. O despertar do Centro-Oeste para a revolução industrial. Metrópoles, 25 maio 2020. Disponível em: <https://bit.ly/3c9Wi2B>. Acesso em: 24 set. 2020.

AURELIANO, L. M. No limiar da industrializaçáo. São Paulo: Brasiliense, 1981.

BÁRCENA, A. et al. La hora de la igualdad: brechas por cerrar, caminos por abrir. Santiago: CEPAL, 2010.

BÁRCENA, A. et al. El septimo decênio de la CEPAL: una reseña de su producción intelectual. In. BIELSCHOWSKY, R.; TORRES, M. (Org.). Desarrollo e igualdad: el pensamiento de la CEPAL en su séptimo decênio - textos seleccionados del período 2008-2018. Santiago: CEPAL, 2018.

BASTOS, C. P.; BRITTO, G. Introdução. In: AGARWALA, A. N.; SINGH, S. P. (Ed.). A economia do subdesenvolvimento. Rio de Janeiro: Contraponto; Centro Internacional Celso Furtado, 2010. p. 406-456.

BELLUZO, L. G. O dólar e os desequilíbrios globais. Revista de Economia Política, v. 25, n. 3, p. 224-232, jul.-set. 2005

BIELSCHOWSKY, R. Pensamento econômico brasileiro: o ciclo ideológico do desenvolvimento. 3. ed. Rio de Janeiro: Contraponto, 1996.

Cinquenta anos de pensamento da CEPAL. Rio de Janeiro: Record, 2000.

BIELSCHOWSKY, R.; TORRES, M. (Ed.). Desarrollo e igualdad: el pensamiento de la CEPAL en su séptimo decenio. Textos seleccionados del período 2008-2018. Santiago: CEPAL, 2018. (Colección 70 años, n. 1). 
BRANDÃO, C. A Busca da utopia do planejamento regional. Revista Paranaense de Desenvolvimento, Curitiba, n. 120, p. 17-37, jan.-jun. 2011.

BRASIL. Ministério da Integração Nacional. Manual das conferências estaduais/distrital. In: CONFERENCIA NACIONAL DE DESENVOLVIMENTO REGIONAL, 1., 2012, Brasília, Distrito Federal. Anais... Brasília: Ministério da Integração Nacional/Secretaria de Desenvolvimento Regional, 2012. Disponível em: <https://bit.ly/3uD6Tth>.

CAIADO, A. S. C. Desconcentração industrial regional no Brasil (1985-1998): pausa ou retrocesso? Campinas: Unicamp, 2002.

CANO, W.; et al. (Org.). Economia paulista: dinâmica socioeconômica entre 1980 e 2005. Campinas: Alínea Editora, 2007.

CANO, W. Questão regional e concentração industrial no Brasil (1930-1970). In: ENCONTRO NACIONAL DE ECONOMIA DA ANPEC, 6., 1978, Gramado, Rio Grande do Sul. Anais... Gramado: Anpec, 5-8 dez. 1978.

Desequilíbrios regionais e concentraçáo industrial no Brasil: 1930-1970. 3. ed. São Paulo: Editora Unesp, 2007a.

$2007 b$

Raízes da concentraçáo industrial em Sáo Paulo. 5. ed. Campinas: Unicamp,

Desconcentraçáo produtiva regional do Brasil: 1970-2005. São Paulo: Unesp, 2008

Novas determinaçóes sobre as questóes regional e urbana após 1980. Revista Brasileira de Estudos Urbanos e Regionais, São Paulo, v. 13, n. 2, p. 27-53, nov. 2011.

CARVALHO, L. Valsa brasileira: do boom ao caos econômico. São Paulo: Todavia, 2018.

CASTRO, A. C.; FONSECA, M. da G. A dinâmica agroindustrial do Centro-Oeste. Brasília: Ipea, 1995.

CAVALCANTE, L. R. Desigualdades regionais em ciência, tecnologia e inovaçáo (CT\&I) no Brasil: uma análise de sua evolução recente. Rio de Janeiro: Ipea, 2011. (Texto para Discussão, n. 1574).

CAVALCANTE, L. R.; DE NEGRI, F. Evolução recente dos indicadores de produtividade no Brasil. In: DE NEGRI, F. (Ed.). Produtividade no Brasil: Desempenho e determinantes. Brasília: ABDI; Ipea, 2014.

CEPAL - COMISIÓN ECONÓMICA PARA AMÉRICA LATINA Y EL CARIBE. Progreso técnico y cambio estructural en América Latina. Santiago de Chile: Naciones Unidas, 2007. 
CIMOLI, M. et al. Cambio estrutural, heterogeneidad productiva y tecnología en América Latina. Santiago de Chile: Naciones Unidas, 2005.

DINIZ, C. C. A dinâmica regional recente da economia brasileira e suas perspectivas. Brasília: Ipea, jun. 1995. (Texto de Discussão, n. 375).

Celso Furtado e o desenvolvimento regional. Nova econ., v. 19, n. 2, p. 227-249, 2009. (ISSN 0103-6351). Disponível em: <https://bit.ly/3yMmR7M>.

DRAIBE, S. Rumos e metamorfoses: um estudo sobre a constituiçáo do Estado e as alternativas da industrializaçáo no Brasil, 1930-1960. Rio de Janeiro: Paz e Terra, 1985.

ESTEVAM, L. A. O tempo da transformação: estrutura e dinâmica da formação econômica de Goiás. Goiânia: Ed. do autor, 1998.

Surgimento e consolidação do agronegócio em Goiás. In: MOYSÉS, A. (Ed.). Cerrados brasileiros: desafios e perspectivas de desenvolvimento sustentável. Goiânia: Editora da PUC Goiás; Editora América, 2012.

FILGUEIRAS, L. et al. Modelo liberal-periférico e bloco de poder: política e dinâmica macroeconômica nos governos Lula. In: MAGALHÁES, J. P. A. et al. Os anos Lula: contribuiçóes para um balanço crítico 2003-2010. Rio de Janeiro: Garamond, 2010.

FREITAS, M. C. P. Panorama e perspectivas das economias avançadas: sob o signo da crise. In: BIASOTO JÚNIOR, G.; NOVAIS, L. F.; FREITAS, M. C. P. Panorama das economias internacional e brasileira: dinâmica e impactos da crise global. São Paulo: Edições Fundap, 2009.

FURTADO, C. Desenvolvimento e subdesenvolvimento. Rio de Janeiro: Fundo de Cultura, 1964.

FURTADO, C. Formação Econômica do Brasil. 32. ed. São Paulo: Companhia Editora Nacional, 2003. (Biblioteca universitária. Serie 2).

Formação de capital e desenvolvimento econômico (1950). Série memórias do desenvolvimento. Cadernos do Desenvolvimento, Rio de Janeiro, ano 1, n. 1, 2006.

2016.

. O subdesenvolvimento revisitado. Economia e Sociedade, v. 1, n. 1, p. 5-19, 27 out.

GUIMARÃES, E. N.; LEME, H. J. C. Caracterização histórica e configuração espacial da estrutura produtiva do Centro-Oeste. Textos NEPO, Campinas, n. 33, p. 21-74, dez. 1997.

GTDN - GRUPO DE TRABALHO DO DESENVOLVIMENTO DO NORDESTE. Uma política de desenvolvimento econômico para o Nordeste. Rio de Janeiro: Departamento de Imprensa Nacional, 1959. 97 p. 
KALDOR, N. The case for regional policies. Scottish Journal of Political Economy, v. 60, n. 5, Nov. 2013.

KUCZYNSKI, P.-P.; WILLIAMSON, J. (Ed.). Depois do Consenso de Washington: retomando o crescimento e a reforma na América Latina. São Paulo: Editora Saraiva, 2004.

KUPFER, D.; ROCHA, C. Dinâmica da produtividade e heterogeneidade estrutural na indústria brasileira. In: EL RETO DE ACELERAR EL CRECIMIENTO EN AMÉRICA LATINA Y EL CARIBE, 2004, Santiago de Chile. Seminário... Santiago de Chile: Cepal, 2004.

LAVINAS, L.; GARCIA, E. H.; AMARAL, M. R. Desigualdades regionais e retomada do crescimento num quadro de integraçáo econômica. Rio de Janeiro: Ipea, mar. 1997. (Texto para discussão, n. 466).

LOPES, H. C. Celso Furtado e o progresso técnico. Revista da Sociedade Brasileira de Economia Política, n. 43, fev.-maio 2016.

MACEDO, F. C. Inserção externa e território: impactos do comércio exterior na dinâmica regional e urbana no Brasil (1989-2008). 2010. 286 f. Tese (Livre-Docência) - Universidade Estadual de Campinas, São Paulo, 2010.

MELLO, J. M. C. de. O capitalismo tardio: contribuição à revisão crítica da formação e do desenvolvimento da economia brasileira. 8. ed. São Paulo: Brasiliense, 1991.

MONTEIRO NETO, A. Desenvolvimento regional em crise: políticas econômicas liberais e restrições à intervenção estatal no Brasil dos anos 1990. Campinas: Unicamp, 2005.

MONTEIRO NETO, A.; SILVA, R. O. Desconcentração territorial e reestruturação regressiva da indústria no Brasil: padróes e ritmos. Brasília: Ipea, 2018. (Texto para Discussão, n. 2402).

MONTEIRO NETO, A.; SILVA, R. O.; SEVERIAN, D. Perfil e dinâmica das desigualdades regionais do brasil em territórios industriais relevantes. In. MONTEIRO NETO, A. (Org.). Desenvolvimento regional no Brasil: políticas, estratégias e perspectivas. Rio de Janeiro: Ipea, 2020.

NACIONES UNIDAS. Heterogeneidad estructural, asimetrías tecnológicas y crecimiento en América Latina. [s.1.]: Naciones Unidas, 2005.

OLIVEIRA, C. A. B. de. Processo de industrializaçáo: do capitalismo originário ao atrasado. Campinas: Unicamp; Unesp, 2003.

PACHECO, C. A. Desconcentração econômica e fragmentação da economia nacional. Revista Economia e Sociedade, n. 6, p. 113-140, jun. 1996. 
PINTO, A. Natureza e implicações da "Heterogeneidade Estrutural" da América Latina. In: BIELSCHOWSKY, R. (Ed.). Cinquenta anos de pensamento da CEPAL. Rio de Janeiro; São Paulo: Record, 2000. v. 2.

PINTO, A. Notas sobre os estilos de desenvolvimento na América Latina. In. BIELSCHOWSKY, R. Cinquenta anos de pensamento da CEPAL. Rio de Janeiro: Record, 2000 (v. 2).

PIRES, M. J. de S.; SANTOS, G. R. Modelo agroexportador, política macroeconômica e a supremacia do mercado: uma visão do modelo brasileiro de exportação de commodities. Brasília: Ipea, mar. 2013. (Texto para Discussão, n. 1817).

PIRES, M. J. de S. As implicaçóes do processo de modernizaçáo conservadora na estrutura e nas atividades agropecuárias da regiáo centro-sul de Goiás. 2008. 146 f. Tese (Doutorado) - Instituto de Economia, Universidade Estadual de Campinas, São Paulo, 2008.

Uma sistematização da discussão sobre heterogeneidade industrial. Um olhar para além das regiōes brasileiras: o caso do Centro-Oeste brasileiro. Brasília: Ipea, 2016. (Texto para Discussão, n. 2257).

. Diagnóstico do Fundo Constitucional de Financiamento do Centro-Oeste (FCO). Revista Planejamento e Políticas Públicas, Brasília, n. 49, jul./dez. 2017.

Estratégia de transformaçáo econômica do Centro-Oeste: o caminho externo. Rio de Janeiro: Ipea, 2019. (Texto para Discussão, n. 2504).

PORCILE, G.; YAMILA, E.; CATELA, A. da S. Heterogeneidade estrutural na produtividade das firmas brasileiras: uma análise para o período 2000-2008. Brasília: Ministério da Fazenda, dez. 2012. (Texto para discussão, n. 8).

PRATES, D. M. A abertura financeira dos países periféricos e os determinantes dos fluxos de capitais. Revista de Economia Política, v. 19, n. 1, p. 73, jan.-mar. 1999.

PRATES, D.; MARÇAL, E. F. O papel do ciclo de preços das commodities no desempenho recente das exportações brasileiras. Análise Econômica, v. 26, n. 49, 2008.

PREBISCH, R. Interpretação do processo de desenvolvimento econômico. Revista Brasileira de Economia - RBE, v. 5, n. 1, dez. 1951.

O desenvolvimento econômico da América Latina e alguns de seus problemas principais. In: CEPAL - COMISSÃO ECONÔMICA PARA A AMÉRICA LATINA E O CARIBE. Cinquenta anos de pensamento na CEPAL. Rio de Janeiro: Record; CEPAL, 2000. v. 1. p. 69-136.

RIBEIRO, F. J.; MARKWALD, R. A balança comercial sob o regime de câmbio flutuante. In: BARROS, O.; GIAMBIAGI, F. (Org.). Brasil globalizado: o Brasil em um mundo surpreendente. Rio de Janeiro: Elsevier, 2008. 
RODRÍGUEZ, O. O estruturalismo latino-americano. Rio de Janeiro: Civilização Brasileira, 2009.

ROSTOW, W. W. The stages of economic growth. The Economic History Review, v. 12, n. 1, p. 1-16, 1959. Disponível em: <https://bit.ly/34BhkTA>.

A decolagem para o crescimento autossustentado. In: AGARWALA, A. N.; SINGH, S. P. (Ed.). A economia do subdesenvolvimento. Rio de Janeiro: Contraponto, p. 406-456, 2010.

SAMUEL, F. Agricultura científica globalizada e fronteira agrícola moderna no Brasil. Confins, n. 17, 2013. Disponível em: <https://bit.ly/3fZqKxN>. Acesso em: 18 mar. 2020.

. Território, capital financeiro e agricultura land grabbing e fronteira agrícola no Brasil. 2018. Tese (Livre-Docência) - Instituto de Geociências e Ciências Exatas, Universidade Estadual Paulista Júlio de Mesquita Filho, Rio Claro, São Paulo, 2018.

SANTOS, M. Por uma outra globalização: do pensamento único à consciência universal. 30 . ed. Rio de Janeiro: Record, 2020.

SCHUMPETER, J. A. Capitalismo, socialismo e democracia. São Paulo: Editora Unesp Digital, 2017.

SILVA, S. Expansão cafeeira e origem da indústria no Brasil. São Paulo: Alpha Ômega, 1976.

SIQUEIRA, H. Dinâmica regional brasileira (1990-2012). In: SIQUEIRA, H.; BRANDÃO, C. (Org.). Pacto federativo, integraçáo nacional e desenvolvimento regional. São Paulo: Editora Fundação Perceu Abramo, 2013.

SQUEFF, G. C.; NOGUEIRA, M. O. A heterogeneidade estrutural no Brasil de 1950 a 2009. [s.l.]: Cepal; Ipea, 2013.

SUNKEL, O. La dependencia y la heterogeneidad estructural. El Trimestre Económico, n. 45, p. 3-20, mar. 1978.

SUZIGAN, W. A industrialização de São Paulo. Revista de Economia Brasileira, Rio de Janeiro, v. 25, n. 2, p. 89-111, abr.-jun. 1971.

Industria brasileira. Origem e desenvolvimento. São Paulo: Editora Hucitec; Editora da Unicamp, 2000.

TAVARES, M. C. Acumulaçáo de capital e industrializaçáo no Brasil. 1974. Tese (Livre-Docência) - Universidade Federal do Rio de Janeiro, Rio de Janeiro, 1974.

TORRES FILHO, E. T.; PUGA, F. Exportações brasileiras: um cenário pós-crise internacional. In: GIAMBIAGI, F.; BARROS, O. (Org.). Brasil pós-crise: agenda para a próxima década. 2. ed. Rio de Janeiro: Elsevier, 2009. 
Ipea - Instituto de Pesquisa Econômica Aplicada

\section{EDITORIAL}

\section{Chefe do Editorial}

Reginaldo da Silva Domingos

\section{Assistentes da Chefia}

Rafael Augusto Ferreira Cardoso

Samuel Elias de Souza

\section{Supervisão}

Camilla de Miranda Mariath Gomes

Everson da Silva Moura

\section{Editoração}

Aeromilson Trajano de Mesquita

Anderson Silva Reis

Cristiano Ferreira de Araújo

Danilo Leite de Macedo Tavares

Jeovah Herculano Szervinsk Junior

Leonardo Hideki Higa

\section{Capa}

Danielle de Oliveira Ayres

Flaviane Dias de Sant'ana

\section{Projeto Gráfico}

Renato Rodrigues Bueno

The manuscripts in languages other than Portuguese published herein have not been proofread.

\section{Livraria Ipea}

SBS - Quadra 1 - Bloco J - Ed. BNDES, Térreo

70076-900 - Brasília - DF

Tel.: (61) 2026-5336

Correio eletrônico: livraria@ipea.gov.br 

Composto em adobe garamond pro 12/16 (texto) Frutiger 67 bold condensed (títulos, gráficos e tabelas) Brasilia-DF 



\section{Missão do Ipea}

Aprimorar as políticas públicas essenciais ao desenvolvimento brasileiro por meio da produção e disseminação de conhecimentos e da assessoria ao Estado nas suas decisões estratégicas.

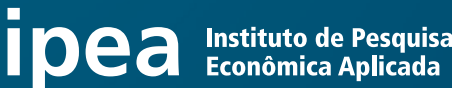 \\ MINISTÉRIO DA \\ ECONOMIA

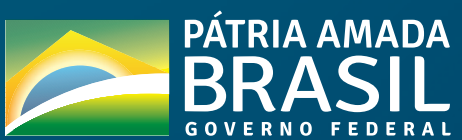

